\title{
Article \\ Effects of Regulated Deficit Irrigation and Early Cluster Thinning on Production and Quality Parameters in a Vineyard cv. Tempranillo under Semi-Arid Conditions in Southwestern Spain
}

\author{
Luis Alberto Mancha ${ }^{1, *(\mathbb{D})}$, David Uriarte ${ }^{1}(\mathbb{D})$, Esperanza Valdés ${ }^{2}\left(\mathbb{D}\right.$, Daniel Moreno ${ }^{2}(\mathbb{D}$ \\ and María del Henar Prieto ${ }^{1}$ (D) \\ 1 Center for Scientific and Technological Research of Extremadura (CICYTEX), Agricultural Research Institute \\ "Finca La Orden-Valdesequera", Highway A-5 km. 372, Guadajira, 06187 Badajoz, Spain; \\ david.uriarte@juntaex.es (D.U.); henar.prieto@juntaex.es (M.d.H.P.) \\ 2 Center for Scientific and Technological Research of Extremadura (CICYTEX), Food and Agriculture \\ Technology Institute of Extremadura (INTAEX), Avenue Adolfo Suárez s/n, 06071 Badajoz, Spain; \\ esperanza.valdes@juntaex.es (E.V.); daniel.moreno@juntaex.es (D.M.) \\ * Correspondence: luisalberto.mancha@juntaex.es; Tel.: +34-924014008
}

Citation: Mancha, L.A.; Uriarte, D.; Valdés, E.; Moreno, D.; Prieto, M.d.H. Effects of Regulated Deficit Irrigation and Early Cluster Thinning on

Production and Quality Parameters in a Vineyard cv. Tempranillo under Semi-Arid Conditions in

Southwestern Spain. Agronomy 2021, 11, 34. https://dx.doi.org/10.3390/ agronomy11010034

Received: 25 November 2020 Accepted: 23 December 2020 Published: 26 December 2020

Publisher's Note: MDPI stays neutral with regard to jurisdictional claims in published maps and institutional affiliations.

Copyright: () 2020 by the authors. Licensee MDPI, Basel, Switzerland. This article is an open access article distributed under the terms and conditions of the Creative Commons Attribution (CC BY) license (https: / / creativecommons.org / licenses/by/4.0/).

\begin{abstract}
The efficient use of water in the vineyard requires knowledge of the crop's response to irrigation in terms of production and quality and the interaction of the same with the environmental conditions. In this work, the behavior of a trellis system vineyard in cv. Tempranillo, located in the south-west of Spain, was analyzed for three years in relation to different irrigation strategies based on crop evapotranspiration $\left(\mathrm{ET}_{\mathrm{c}}\right)$, and with two levels of crop load established by early cluster thinning. The response of the vineyard to the same irrigation strategy varied depending on the characteristics of the year. The vineyard's biomass production increased in a linear trend as annual water status improved. However, during pre-veraison, the water status had a more significant impact on the harvest by affecting bud fertility. The increase in individual cluster weight only partially compensated the loss of yield caused by cluster thinning. The year's characteristics highly conditioned the response to the irrigation treatment and, together with cluster thinning, modified the characteristics of the musts, although the response was varied.
\end{abstract}

Keywords: water status; crop load; phenological sensitivity; vegetative growth; yield; must characteristics; dry matter

\section{Introduction}

Water is an essential production factor in agriculture, especially in semiarid areas where rainfall does not meet the demand for crops. Winegrowing is no exception.

Although the vine is well adapted to water shortages due to the depth and extent of its roots and to drought resistance mechanisms such as control of stomatal opening [1] and osmotic adjustment [2], increasing water availability for the plant means a radical change in its physiology $[3,4]$. These physiological changes decisively affect the grapes' fruiting and ripening processes and the characteristics of the musts [5-8].

Knowing when and how much water to apply is essential to achieve, on the one hand, efficient management of this increasingly scarce and expensive natural resource and, on the other, to maintain farm profitability by balancing productivity and grape quality. Thus, correct water application requires precise knowledge of the vine's response to water stress in its different phenological states to identify the periods of least sensitivity of the grape and define the best irrigation strategy to be applied. The period of greatest vegetative growth on the vine occurs from bud break to the cessation of shoot growth, which occurs near veraison [8]. Water stress conditions during this period decrease shoot growth and 
leaf area in vine [9]. This effect will be more pronounced the earlier the stress is present and used as a growth control tool in high vigorous plantations. On the other hand, after veraison, water stress has little or no effect on leaf area development [10-12] as long as the vine stress is not severe, since high stress produces premature senescence of the leaves and a limitation in the translocation of photoassimilates to the bunches and reserve organs.

Vegetative growth decreases as berry growth and development become evident, so that the cluster becomes the main sink for photoassimilation to the detriment of the vegetative apices, which end up stopping their growth. The multiplication and elongation of berry cells decrease in response to early water stress, resulting in smaller berries [13]. This smaller berry size has been associated with increases in must quality as a result of the increased skin/pulp ratio [12]. However, [14] reported that vine management throughout the cultivation cycle had a more significant influence on berry composition than on berry size.

Stress management through irrigation has also been used in hot climate areas as a tool to improve berry and wine composition [15-23]. During pre-veraison, water stress produces metabolic changes in the berry, which are maintained even though later this stress decreases $[20,24]$. In contrast, the effects on berry of water stress during post-veraison are much more variable, generating greater discrepancy between the results obtained [25-28]. However, it can be generalized that moderate water stress improves crop quality by decreasing berry size and total acidity but increases the soluble solids content and the total concentration of anthocyanins and polyphenols [29].

Intercepted solar radiation is the most crucial factor determining water consumption in vines [30]. It is ultimately responsible for leaf photosynthetic activity, overall productivity, and vine quality through the relationship between exposed leaf area and fruit weight [31-35].

Numerous studies have shown that a proper balance between vegetative growth and yield is necessary to improve berry quality [31,33]. This source-sink relationship is influenced by environmental factors and cultural practices to modify the amount of vegetation and illumination of the clusters $[36,37]$ or the yield level, decreasing productivity [12,38]. In some fruit trees, fruit load adjustment has been proposed as a technique to improve the water status under conditions of limited water availability $[39,40]$. In the vineyard, [41,42] report that this load regulation does not affect vine water status, nor does it favor increases in leaf area, which is why cluster thinning is understood as a tool used to improve grape quality at the expense of a decrease in yield. However, studies conducted by $[43,44]$ have shown that a reduction in yield is not necessarily associated with significant changes in grape quality and that the final effects on wine quality depend on the timing and intensity of harvest crop load regulation [45]. In this regard, although some studies have reported that cluster thinning increases the concentration of sugars and anthocyanins [46,47], others concluded that this effect is slight or non-existent $[41,44,48]$. However, other results obtained with cv. Tempranillo indicate that, at the same sugar concentration, cluster thinning reduces acidity and increases $\mathrm{pH}$ [42]. This diversity of results suggests that cluster thinning effects depend on soil, climate, genetic factors, and possible variations in this practice's implementation.

The effect of both irrigation strategy and cluster thinning depends mainly on the agro-climatic conditions. Although cv. Tempranillo is the variety with the largest planting area in Spain, there is still not enough information on its response to different irrigation strategies under high temperature conditions during ripening, nor on the combined effect of irrigation strategies and early cluster thinning. This work analyzes the impact of several deficit irrigation strategies combined with different cluster load levels, adjusted in setting, on vegetative development, production, and quality of Tempranillo grapes under southwestern Spain's growing conditions. 


\section{Materials and Methods}

\subsection{Location and Vineyard Description}

The trial was established for three years $(2009,2010$, and 2011) in an experimental vineyard located in "Finca La Orden" (Badajoz, Spain). The vineyard is located in Las Vegas Bajas del Guadiana ( $38^{\circ} 51^{\prime} \mathrm{N}, 6^{\circ} 40^{\prime} \mathrm{W}$, altitude $\left.188 \mathrm{~m}\right)$. The area's climate is Mediterranean with moderate Atlantic influence, with very hot and dry summers and mild winters, presenting irregular rainfall with an average of $450 \mathrm{~mm}$ per year. The soil is alluvial with a loamy to sandy texture, slightly acidic, and low organic matter content.

The experimental vineyard has an area of 1.7 ha of cv. Tempranillo on Richter 110 rootstock planted in 2001 on a trellis, formed in a double Royat cordon leaving six spurs per plant and two buds per spur, with a trunk height of $0.60 \mathrm{~m}$, trellis height of $1.50 \mathrm{~m}$, and a planting frame of $2.5 \times 1.2 \mathrm{~m}$ (3333 plants/ha), with E-W row orientation. In spring, pruning was carried out to adjust to 12 shoots per vine, with several clippings, depending on the year, to contain the vegetation on the trellis following the area's cultural practices.

A drip irrigation system was in place with two emitters of $4 \mathrm{~L} \mathrm{~h}^{-1}$ per plant, with the differential treatments carried out through programmed solenoid valves in the field.

\subsection{Treatments and Irrigation Management}

Four treatments were established in 2009: rainfed (T1), which did not receive any water input through irrigation; pre-veraison deficit (T2), which received 25\% of crop evapotranspiration $\left(\mathrm{ET}_{\mathrm{C}}\right)$ from the beginning of irrigation until veraison, and $75 \%$ after veraison; post-veraison deficit (T3), which received $75 \% \mathrm{ET}_{\mathrm{c}}$ from the beginning of irrigation until veraison and $25 \%$ after veraison, and control (T4), which received $100 \% \mathrm{ET}_{\mathrm{C}}$ throughout the irrigation period. In the years 2010 and 2011, the percentages used in the regulated deficit irrigation (RDI) treatments, T2 and T3, were 56 and 19\%, to increase the contrasts between treatments.

Two crop load levels were established for each irrigation treatment except T4: high load (A) (no cluster thinning) and low load (B) (with cluster thinning). Cluster thinning was carried out at fruit set, eliminating one cluster per shoot.

The experimental design was of randomized blocks with four repetitions per treatment for the irrigation treatments (16 subplots), and divided plots when considering irrigation $x$ cluster thinning (24 subplots). The subplot comprised six rows of 18 vines each row (108 vines per subplot), considering the outer rows as borders, another two rows for destructive determinations, and another 2 for non-destructive determinations. The same vines were selected for all treatments during the 3 years of the study.

ET $_{\mathrm{C}}$ was determined in a weighing lysimeter of $2.67 \times 2.25 \mathrm{~m}$ and installed to a depth of $1.5 \mathrm{~m}$ in an area of the experimental vineyard, which contained two vines irrigated to $100 \%$ of their $\mathrm{ET}_{\mathrm{C}}$ and developed in the same conditions as the rest of the plot surrounding it [49].

Irrigation was initiated when a threshold value of the stem water potential at midday $\left(\psi_{\mathrm{s}}{ }^{\mathrm{md}}\right)$ of $-0.6 \mathrm{MPa}$ was reached for optimal irrigation in pre-veraison (T3 and T4), and a $\psi_{\mathrm{s}}{ }^{\text {md }}$ value of $-1.0 \mathrm{MPa}$ for the treatment of moderate water stress in pre-veraison (T2). After veraison, irrigation was cut in the RDI treatments and was not restarted until threshold $\psi_{\mathrm{s}}$ md values of -0.8 and $-1.2 \mathrm{MPa}$ were reached for optimal irrigation (T2) and moderate water stress (T3), respectively.

Irrigation was applied five to six times per week, measuring the amount of water applied to each subplot through volumetric water meters and maintaining irrigation until the beginning or middle of October.

\subsection{Climate and Phenology}

Phenological monitoring was carried out according to [50,51] so that from mid-March, coinciding with the so-called "cotton bud" phenological stage, a weekly visual inspection was carried out. This phenological monitoring was carried out independently for each subplot, selecting ten control plants and noting on each day of observation the most 
delayed, the most advanced, and the most representative (in which there were at least 50\% of vines) phenological states.

Meteorological data and reference evapotranspiration $\left(\mathrm{ET}_{\mathrm{o}}\right)$ were obtained from an agrometeorological station and a weighing lysimeter located $100 \mathrm{~m}$ from the experimental vineyard, in a polyphytic meadow [52].

The degree days (DD) were calculated using $10^{\circ} \mathrm{C}$ as the base temperature $[53,54]$.

\subsection{Water Status}

The $\psi_{\mathrm{s}}{ }^{\text {md }}$ was measured from leaves on the north side, in the lower zone of the vine, near the trunk and wrapped in aluminum foil $2 \mathrm{~h}$ before the time of measurement, with a pressure chamber (Soil Moisture Corp., Model 3500, Santa Barbara, CA, USA), according to the procedure described by [55]. The measurement frequency was weekly, measuring one leaf per plant, in two plants per subplot.

\subsection{Vegetative Growth}

The fraction of photosynthetically active radiation intercepted by the vineyard (FiPAR) was determined by measuring the radiation at ground level with a $0.80 \mathrm{~m}$ PAR radiation ceptometer (Accupar LP-80 from Decagon Device) on eight vines per treatment (two per block), performing six transects per plant (2 measurements per transect), in high crop load treatments. The measurements were taken at noon on clear days since flowering, with a biweekly frequency. The linear sensor was placed horizontally at ground level, covering the planting frame and perpendicular to the vines. At the beginning and end of the data collection, two other measurements were performed in an open site and without interference from vegetation, serving as a reference of the total PAR radiation at ground level in the measurement session. The measures were weighted by their representativeness within the transect, adding those of the same transect to obtain a single value (Scheme 1). Subsequently, the average value of each subplot's 12 transects was obtained, thus obtaining the PAR radiation that arrives at ground level, which by difference with the reference measurement of the PAR radiation gives us the PAR radiation intercepted by the crop. The FiPAR is the result of dividing this difference by the reference of the PAR radiation.

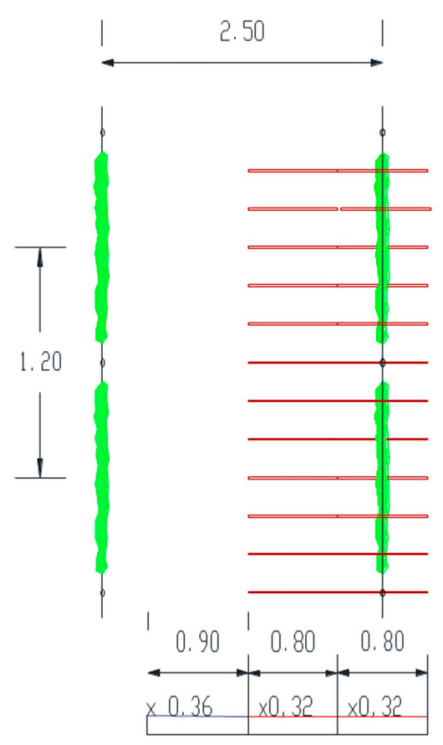

Scheme 1. Methodology for measuring photosynthetically active radiation (PAR) radiation, with the dimensions in meters and the weighting values of each measurement.

\subsection{Production of Biomass and Yield Components}

Ten plants were selected by subplots (high load sub-plots), and the fresh weight and dry weight in the different interventions carried out were determined: clipping (removal 
of the tip of the shoots at different times of the herbaceous phase of the shoots); harvesting; pruning (removal of branches during dormancy excluding leaves fallen in senescence). A precision balance (Sartorius Mechatronics BP61S, Göttinger, GER) with a sensitivity of $0.01 \mathrm{~g}$ was used to determine the weight. A forced ventilation stove was used to dry the samples at $65^{\circ} \mathrm{C}$, and the samples were kept there until they reached a constant weight.

Harvesting was performed, on all sub-plots, when a concentration of soluble solids close to $23^{\circ}$ Brix (average value of each treatment) was reached. At harvest, all the clusters from the ten selected plants of each subplot were weighed and counted, both high and low loading, differentiating them. Berry weight was determined by sampling each subplot at harvest and weighing 100 berries.

\subsection{Water Productivity}

Water productivity (WP) was differentiated into two components, vegetative and productive. The vegetative component was determined as the ratio between the dry weight (g/plant) of clippings and pruning, except leaves in senescence, and the water received (L/plant) both through irrigation and total rainfall in the period from budbreak to harvest. Water supplied to each plant through irrigation was calculated by reading the volumetric meters installed in each subplot and divided by the number of vines in each subplot. In contrast, each plant's rainfall was calculated from data obtained from a nearby agrometeorological station by multiplying this value by the area occupied by each vine. The efficiency attributed to the productive component was determined as the relationship between the fresh weight at harvest (g/plant) and the water received ( $\mathrm{L} /$ plant) from irrigation plus precipitation for the same period.

\subsection{Must Quality Parameters}

At harvest, samples of grapes were taken from each subplot. The samples were crushed and blended, after manual removal of the pedicel, using a commercial blender (Taurus BAPI 850 INOX 916.251, Oliana, Spain) with speed control. The resulting must was separated into portions, measuring all the quality parameters under study.

The total soluble solids content (TSS) was determined using a digital refractometer (ATAGO PR32 Alpha, Tokyo, Japan) with a sensitivity of $0.2 \%$ and temperature compensation.

$\mathrm{pH}$ and total acidity expressed as $\mathrm{g} / \mathrm{L}$ of tartaric acid were determined by titration with a $0.1 \mathrm{~N} \mathrm{NaOH}$ solution to an endpoint of $\mathrm{pH} 8.2$, with an automatic titrator (CRISON Micro TT), following the official methodology of the International Organisation of Vine and Wine [56].

Tartaric acid (TH2, g/L) and malic acid (MH2, g/L) were analyzed by spectrophotometry, following the Rebelein [57] and the enzymatic reaction methods, respectively, in an automatic analyzer (Chem Easy Plus, Systea R\&D group, Anagni, Italy).

Potassium was determined using an atomic absorption spectrophotometer (AA 240 FS, Varian, CA, USA), according to the official methodology [56].

Total polyphenols and anthocyanins were determined following the procedure proposed by the Australian Wine Research Institute and described in [58].

\subsection{Statistical Analysis}

The results were subjected to a one-way and two-way (irrigation $x$ load) analysis of variance (ANOVA) for each year, using the general linear model, considering irrigation as the main factor and load as a subplot of the design-divided plots. The comparison of means for the four irrigation treatments at high load was done by the Tukey test with a significance level $p<0.05$. To analyze the effect of load on each irrigation treatment, the year and treatment to be analyzed were selected (except T4), comparing the means using a T-test for independent samples. The interaction between the factors considered was done through multivariate analysis.

The analyses were carried out using SPSS version 20 (IBM, Armonk, NY, USA). 


\section{Results}

\subsection{Weather Conditions, Irrigation, and Phenology}

As can be seen in Table 1, the rainfall recorded was very different in the three years under study: 2009 was the driest year, with $324 \mathrm{~mm}$ of rain from leaf fall in the previous year to the current year's harvest, of which $82.6 \mathrm{~mm}$ was recorded from budbreak to harvest. In 2010 and 2011, rainfall was 656 and $458 \mathrm{~mm}$, respectively, of which 109 and $159 \mathrm{~mm}$ were recorded from budbreak to harvest (Table 1). As a result, in 2009, irrigation began on 20 May, when the threshold value of $\psi_{\mathrm{s}}{ }^{\text {md }}$ was reached, while in 2010 and 2011, it was delayed until 25 June and 21 June, respectively.

Table 1. Reference evapotranspiration $\left(\mathrm{ET}_{\mathrm{o}}\right)$ and crop evapotranspiration $\left(\mathrm{ET}_{\mathrm{c}}\right)$, rainfall, and volumes of irrigation water in each of the treatments between budbreak and harvest in 2009, 2010, and 2011.

\begin{tabular}{|c|c|c|c|c|c|c|c|c|c|}
\hline \multirow{2}{*}{ Year } & \multirow{2}{*}{$\begin{array}{c}\text { Period } \\
\text { (Budbreak-Harvest) }\end{array}$} & \multirow[t]{2}{*}{$\mathrm{ET}_{\mathrm{o}}(\mathrm{mm})$} & \multirow[t]{2}{*}{$\mathrm{ET}_{\mathrm{c}}(\mathrm{mm})$} & \multirow{2}{*}{$\begin{array}{c}\text { Rainfall (mm) } \\
\text { (Budbreak-Harvest) }\end{array}$} & \multirow{2}{*}{$\begin{array}{c}\text { Rainfall (mm) } \\
\text { (Leaf Fall-Harvest) }\end{array}$} & \multicolumn{4}{|c|}{ Irrigation (mm) } \\
\hline & & & & & & $\mathrm{T} 4$ & T3 & $\mathrm{T} 2$ & $\mathrm{~T} 1$ \\
\hline 2009 & DOY 79-244 & 958 & 591 & 83 & 324 & 529 & 239 & 229 & 0 \\
\hline 2010 & DOY 85-256 & 978 & 633 & 109 & 656 & 505 & 129 & 155 & 0 \\
\hline 2011 & DOY 83-249 & 913 & 479 & 159 & 458 & 366 & 52 & 152 & 0 \\
\hline Average & DOY 82-250 & 950 & 568 & 117 & 479 & 467 & 140 & 179 & 0 \\
\hline
\end{tabular}

The $\mathrm{ET}_{\mathrm{c}}$, from budbreak to harvest, varied between $633 \mathrm{~mm}$ in 2010 and $479 \mathrm{~mm}$ in 2011 (Table 1).

The average volume of irrigation water for the three years was $467 \mathrm{~mm}$ in T4, $179 \mathrm{~mm}$ in T2, and $140 \mathrm{~mm}$ in T3 (which correspond to 38 and $30 \%$ of T4, respectively). The lowest irrigation in all the treatments was applied in the 2011 season, coinciding with the rainiest season, with $\mathrm{T} 3$ receiving just $52 \mathrm{~mm}$ (Table 1).

Neither irrigation nor load treatment affected phenological development on the vines, except for the ripening period, which decreased by an average of 2 weeks in the low load treatments.

The duration in days of the period between budbreak and harvest was similar in the three years, ranging from 165 days in 2009 to 171 in 2010, accumulating higher DD as the period increased (1712 and 1928 DD for 2009 and 2010, respectively) (Table 2).

Table 2. Phenological stages in day of the year (DOY), degree days (DD), and period duration from budbreak to harvest in the years 2009, 2010, and 2011.

\begin{tabular}{|c|c|c|c|c|c|c|c|c|}
\hline \multirow{2}{*}{$\begin{array}{c}\text { Phenological } \\
\text { Stages }\end{array}$} & \multicolumn{2}{|c|}{2009} & \multicolumn{2}{|c|}{2010} & \multicolumn{2}{|c|}{2011} & \multicolumn{2}{|c|}{ Average } \\
\hline & DOY & DD & DOY & DD & DOY & DD & DOY & DD \\
\hline Budbreak & 79 & 107 & 85 & 118 & 83 & 82 & 82 & 102 \\
\hline Anthesis & 131 & 241 & 137 & 259 & 129 & 315 & 132 & 272 \\
\hline Fruit set & 146 & 354 & 152 & 419 & 136 & 398 & 145 & 390 \\
\hline Veraison & 196 & 1005 & 200 & 1063 & 192 & 1073 & 196 & 1047 \\
\hline Harvest $^{1}$ & 244 & 1712 & 256 & 1928 & 249 & 1860 & 250 & 1834 \\
\hline Budbreak-Harvest time & \multicolumn{2}{|c|}{165 days } & \multicolumn{2}{|c|}{171 days } & \multicolumn{2}{|c|}{166 days } & \multicolumn{2}{|c|}{168 days } \\
\hline
\end{tabular}

${ }_{1}^{1}$ The harvest of high loads is considered.

\subsection{Vineyard Water Status}

The $\psi_{t}{ }^{\text {md }}$ for the T4 treatment remained above $-0.7 \mathrm{MPa}$ in 2010 and 2011. In 2009, there was a seasonal decline in the potential for this treatment to -1.0 MPa due to underestimation of $\mathrm{ET}_{\mathrm{c}}$ in the lysimeter as described by [49].

During the three years of the experiment, differences were established in the water status of the treatments before or after veraison, depending on the irrigation strategy, although to a greater or lesser extent also depending on the year's characteristics. In 2009, there was a rapid initial decline of $\psi_{\mathrm{s}}{ }^{\mathrm{md}}$, which explains the early start of irrigation in T3 
and T4 in relation to the two following years (Figure 1). Clear differences were established in pre-veraison between the four treatments; at the beginning of irrigation, T3 and T4 differed from the two non-irrigated treatments; on day 176 , the $\psi_{\mathrm{s}}{ }^{\mathrm{md}}$ of $\mathrm{T} 2$ recovered at the beginning of irrigation in this treatment, which is separate from T1 so that the four treatments reach differentiated veraison. In post-veraison, there is a progressive recovery of the water status in all the treatments, which can be grouped in pairs differentiating between the more and less irrigated ones until they are equalized at the end of the crop cycle. The three deficit treatments reached minimum potential values close to $-1.3 \mathrm{MPa}$, which, according to [59], corresponds to a moderate to severe water deficit.

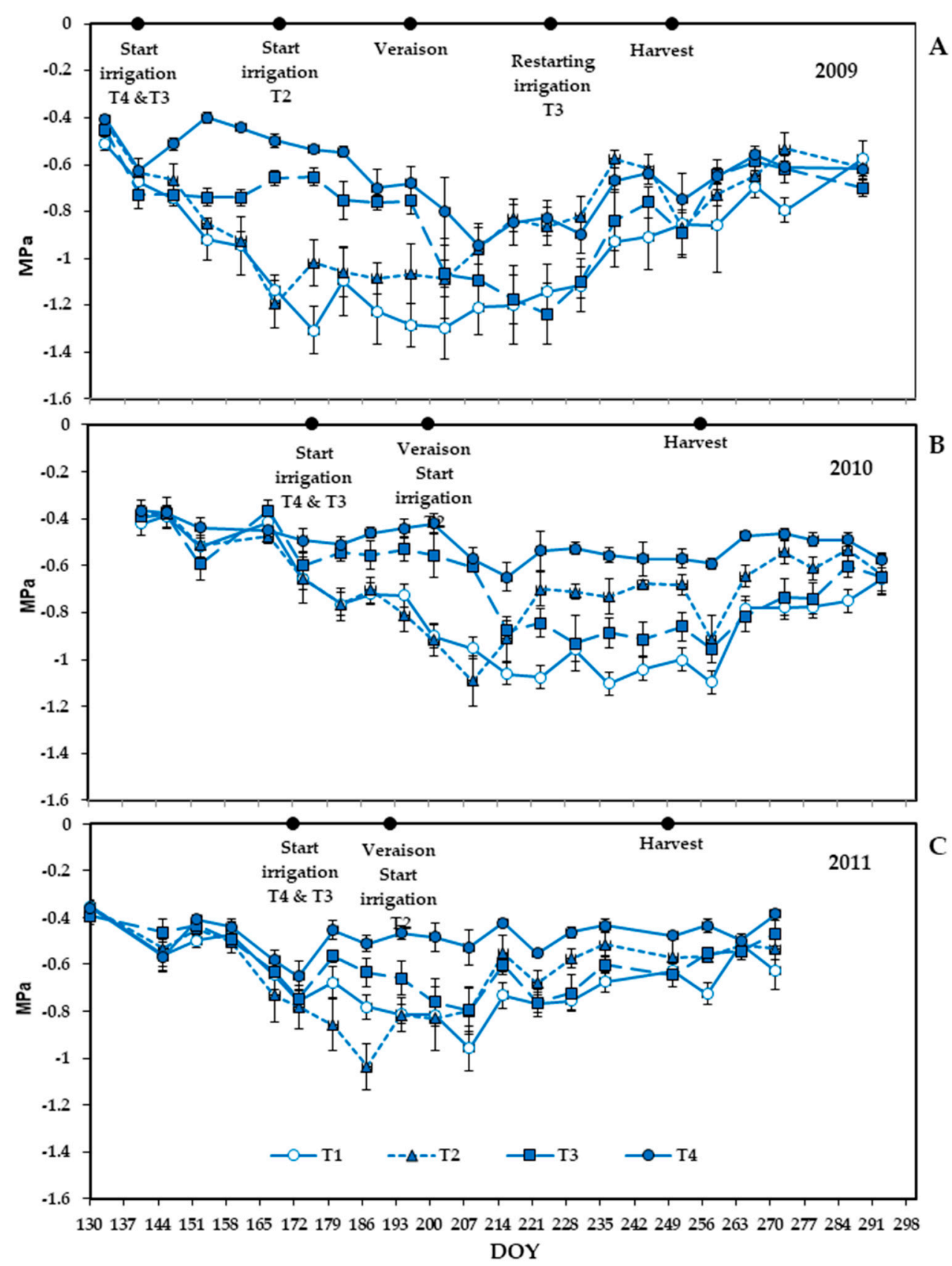

Figure 1. Seasonal evolution of stem water potential measured at midday $\left(\psi_{\mathrm{s}}{ }^{\mathrm{md}}\right)$ in the four irrigation treatments in years (A) 2009, (B) 2010, and (C) 2011. Each point is the average of the four elementary high load plots. The bars represent the standard error of the average. 
In the two subsequent years (Figure $1 B, C$ ), although with a seasonal trend similar to the first year, the decline of $\psi_{\mathrm{s}}{ }^{\text {md }}$ during pre-veraison was less pronounced, reaching higher minimum values in deficit treatments (-1.1 and $-1.0 \mathrm{MPa}$ for 2010 and 2011, respectively) due to higher rainfall before budbreak and during spring. Therefore, the level of stress supported by the vines was lower, even in 2010 with a higher $\mathrm{ET}_{\mathrm{o}}$ (Table 1). In 2010, the four treatments had different $\psi_{\mathrm{s}}{ }^{\mathrm{md}}$ during part of the post-veraison period before coming back together at the end of the cycle. Finally, in 2011 the differences between treatments in $\psi_{\mathrm{s}}{ }^{\mathrm{md}}$ were less, starting late in the pre-veraison period and coming back together again close to the harvest.

As shown in Figure 2, there is substantial parallelism between the seasonal evolution of $\psi_{\mathrm{s}}{ }^{\mathrm{md}}$ in $\mathrm{T} 1$ and the evaporative demand measured as $\mathrm{ET}_{\mathrm{o}}$ in the three years of testing. This parallelism is maintained even with differences between years in the minimum values of $\psi_{\mathrm{s}}{ }^{\mathrm{md}}$, drier in 2009 and reaching values below $-1.2 \mathrm{MPa}$ (Figure 2A), and higher in 2011 with values above $-1.1 \mathrm{MPa}$ (Figure 2C).

$\mathrm{MPa}$

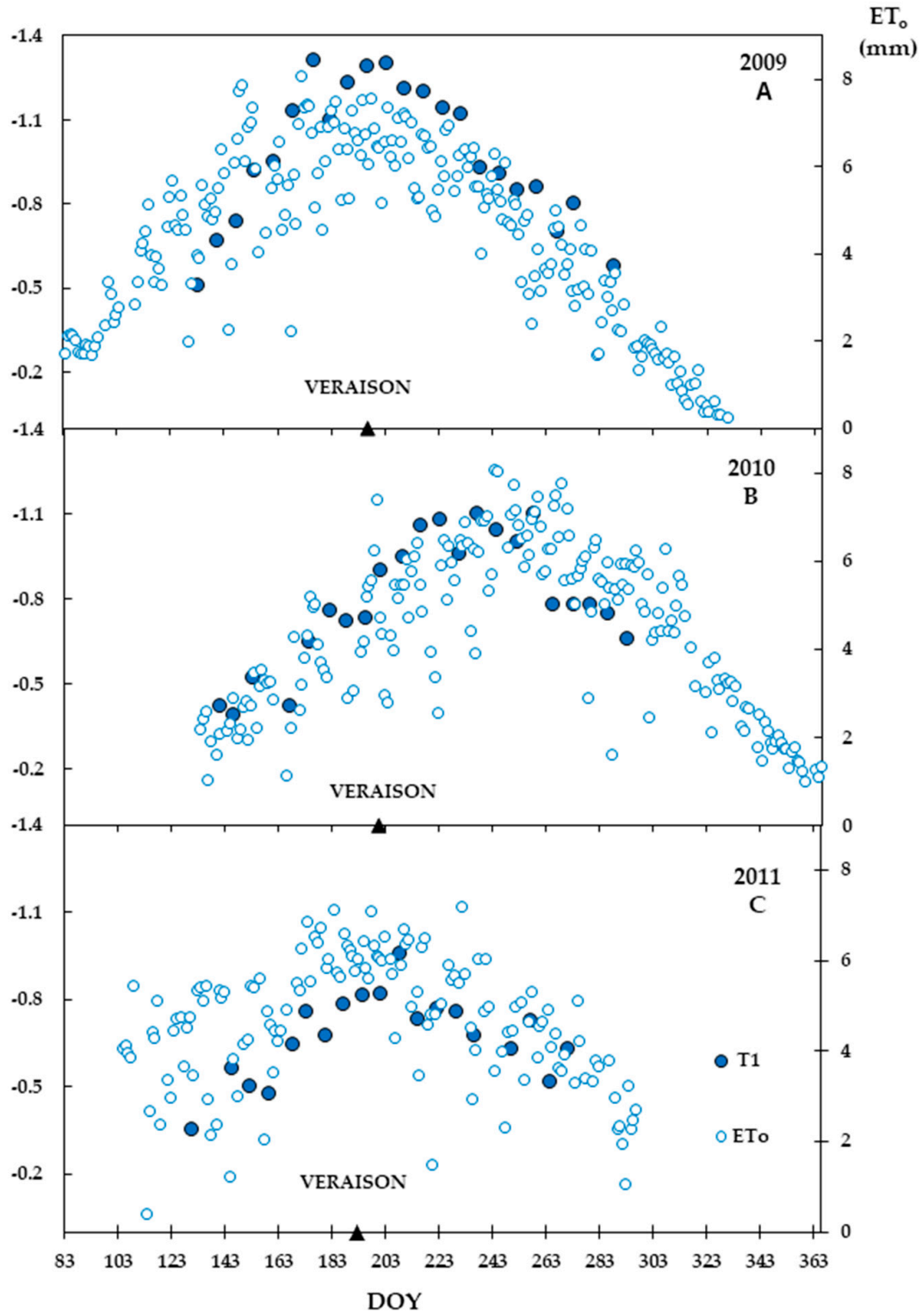

Figure 2. Seasonal evolution of stem water potential measured at midday $\left(\psi_{\mathrm{s}}{ }^{\mathrm{md}}\right)$ in rainfed treatment $(\mathrm{T} 1)$ and $\mathrm{ET}_{\mathrm{O}}$ obtained with the weighing lysimeter in the years (A) 2009, (B) 2010, and (C) 2011. Each point of $\psi_{t}$ md represents the average value of 4 high load subplots. 
Table 3 shows the average $\psi_{\mathrm{s}}{ }^{\mathrm{md}}$ for the pre-veraison, post-veraison, and budbreak to harvest periods for irrigation treatments and load levels. In no year did load level affect vine water status, and there was no interaction between irrigation and crop load. During the three years, there were significant differences in water status due to irrigation treatments in the pre-veraison and post-veraison periods, and from budbreak to harvest. The lowest average $\psi_{\mathrm{s}}{ }^{\mathrm{md}}$ values were those for 2009, followed by 2010 and finally 2011. Despite these year-on-year differences, the $\psi_{\mathrm{s}}{ }^{\mathrm{md}}$ treatments were ordered in the pre-veraison and postveraison periods according to the volume of water received in all years. When considering the total period, the T3 strategy maintained the plants in a better or similar water status than T2, but with a lower volume of water in 2010 and 2011, while in 2009 the volume of water applied in T3 was slightly higher (Table 1).

Table 3. Average stem water potential at midday $\left(\psi_{\mathrm{s}}{ }^{\mathrm{md}}\right)$ in pre-veraison (Pre-v) and post-veraison (Post-v) periods and in both periods (Total) in the four irrigation treatments and two load levels in the years 2009, 2010, 2011.

\begin{tabular}{|c|c|c|c|c|c|c|c|c|c|}
\hline$\psi_{\mathrm{s}}^{\mathrm{md}}$ & & 2009 & & & 2010 & & & 2011 & \\
\hline Treatment & Pre-v & Post-v & Total & Pre-v & Post-v & Total & Pre-v & Post-v & Total \\
\hline Irrigation & $* * *$ & $* *$ & $* * *$ & $* * *$ & $* * *$ & $* * *$ & $* * *$ & $* * *$ & $* * *$ \\
\hline $\mathrm{T} 1$ & $-0.98 c$ & $-0.99 \mathrm{~b}$ & $-0.99 c$ & $-0.58 b$ & $-0.92 c$ & $-0.80 \mathrm{c}$ & $-0.66 c$ & $-0.71 c$ & $-0.67 b$ \\
\hline $\mathrm{T} 2$ & $-0.89 c$ & $-0.76 \mathrm{a}$ & $-0.83 b$ & $-0.59 b$ & $-0.69 \mathrm{ab}$ & $-0.68 b$ & $-0.59 \mathrm{bc}$ & $-0.59 \mathrm{~b}$ & $-0.64 b$ \\
\hline T3 & $-0.70 b$ & $-0.89 a b$ & $-0.81 b$ & $-0.50 \mathrm{a}$ & $-0.82 b c$ & $-0.68 b$ & $-0.55 \mathrm{ab}$ & $-0.63 b c$ & $-0.60 b$ \\
\hline $\mathrm{T} 4$ & $-0.53 \mathrm{a}$ & $-0.73 \mathrm{a}$ & $-0.64 \mathrm{a}$ & $-0.50 \mathrm{a}$ & $-0.54 \mathrm{a}$ & $-0.50 \mathrm{a}$ & $-0.50 \mathrm{a}$ & $-0.47 \mathrm{a}$ & $-0.48 \mathrm{a}$ \\
\hline $\begin{array}{l}\text { Crop } \\
\text { Load }\end{array}$ & ns & ns & ns & ns & ns & ns & ns & ns & ns \\
\hline Low & -0.78 & -0.81 & -0.8 & -0.52 & -0.74 & -0.66 & -0.55 & -0.6 & -0.59 \\
\hline High & -0.78 & -0.84 & -0.82 & -0.53 & -0.74 & -0.67 & -0.57 & -0.6 & -0.6 \\
\hline Interaction & ns & ns & ns & ns & $\mathrm{ns}$ & ns & ns & ns & ns \\
\hline
\end{tabular}

For the Tukey test, different letters within the same column indicate significant differences between irrigation treatments for $p<0.05$. *****, indicate significant differences for $p<0.01$ and $p<0.001$, respectively; ns, not significant.

\subsection{Vegetative Growth}

FiPAR increased from budbreak as the crop cycle advanced until reaching the highest values during post-veraison. The successive interventions on the vegetation (green pruning, clipping, guiding, etc.) had the effect of homogenizing the exposed leaf surface, reducing the effect of the irrigation treatments on radiation capture. This effect was more evident in 2010, where interventions on vegetation were more intense than for the rest of the years under study (data not shown). According to the data presented in Table 4, the lowest FiPAR values correspond to the rainfed treatment, with a vegetative development in accordance with the year's characteristics and with average total FiPAR increasing each year. The T4 treatment had the highest values, which decreased in 2010 due to interventions on the vegetation (Table 4).

\subsection{Yield}

As shown in Table 5, irrigation treatment significantly affected production per plant and average weight of clusters in the three years of the trial, while number of clusters per vine was only affected in the first two years. However, in no case did irrigation modify the average weight of the berries. 
Table 4. Fraction of interception of PAR radiation (FiPAR) in \% (average values per period) of the irrigation management treatments at high load in pre-veraison (Pre-v), post-veraison (Post-v), and throughout the period (Total), in the years 2009, 2010, and 2011.

\begin{tabular}{cccccccccc}
\hline FiPAR & \multicolumn{3}{c}{$\mathbf{2 0 0 9}$} & & & $\mathbf{2 0 1 0}$ & & \multicolumn{2}{c}{$\mathbf{2 0 1 1}$} \\
\hline Treatment & Pre-v & Post-v & Total & Pre-v & Post-v & Total & Pre-v & Post-v & Total \\
\hline Irrigation & $* *$ & $* * *$ & $* * *$ & ns & ns & ns & ns & $*$ & ns \\
\hline T1 & $20.60 \mathrm{~b}$ & $26.36 \mathrm{~b}$ & $23.68 \mathrm{c}$ & 23.12 & 26.1 & 24.4 & 30.28 & $31.24 \mathrm{~b}$ & 30.74 \\
T2 & $25.02 \mathrm{~b}$ & $37.66 \mathrm{a}$ & $32.33 \mathrm{a} \mathrm{b}$ & 27.14 & 27.38 & 27.24 & 29.85 & $34.30 \mathrm{ab}$ & 31.86 \\
T3 & $23.49 \mathrm{~b}$ & $36.80 \mathrm{a}$ & $30.75 \mathrm{~b}$ & 28.83 & 31.2 & 29.84 & 29.91 & $35.33 \mathrm{ab}$ & 32.34 \\
T4 & $32.32 \mathrm{a}$ & $41.62 \mathrm{a}$ & $37.54 \mathrm{a}$ & 30.06 & 33.38 & 31.52 & 33.55 & $40.87 \mathrm{a}$ & 36.86 \\
\hline
\end{tabular}

For the Tukey test, different letters within the same column indicate significant differences between irrigation treatments for $p<0.05 . * * *$, $* * *$, indicate significant differences for $p<0.05, p<0.01$, and $p<0.001$, respectively; ns, not significant.

Table 5. Yield and yield components in the different irrigation and load treatments, in the years 2009, 2010 , and 2011.

\begin{tabular}{|c|c|c|c|c|c|c|c|}
\hline \multirow{2}{*}{ Treatment } & \multirow{2}{*}{ Crop Load } & \multicolumn{3}{|c|}{ No. Clusters } & \multicolumn{3}{|c|}{ Yield (kg/vine) } \\
\hline & & 2009 & 2010 & 2011 & 2009 & 2010 & 2011 \\
\hline \multirow{2}{*}{$\begin{array}{l}\text { Irrigation } \\
\text { Crop load }\end{array}$} & & $* * *$ & $* * *$ & ns & $* * *$ & $* * *$ & $* * *$ \\
\hline & & $* * *$ & $* * *$ & $* * *$ & $* *$ & $* * *$ & ns \\
\hline \multirow[b]{2}{*}{$\mathrm{T} 1$} & Low & $11.2 * * *$ & $9.8^{* * *}$ & $12.2 * * *$ & $2.7^{\mathrm{ns}}$ & $3.4^{\mathrm{ns}}$ & $3.9^{* * *}$ \\
\hline & High & $15.4 \mathrm{~b}$ & $15.0 \mathrm{~b}$ & 21.9 & $2.6 \mathrm{c}$ & $4.2 \mathrm{c}$ & $4.8 \mathrm{~b}$ \\
\hline \multirow{2}{*}{$\mathrm{T} 2$} & Low & $12.2 * * *$ & $11.2 * * *$ & $12.2^{* * *}$ & $3.6^{* * *}$ & $4.7^{* *}$ & $6.5^{\mathrm{ns}}$ \\
\hline & High & $18.9 \mathrm{a}$ & $16.3 \mathrm{~b}$ & 21.7 & $4.4 \mathrm{~b}$ & $5.7 \mathrm{~b}$ & $6.6 \mathrm{a}$ \\
\hline \multirow{2}{*}{ T3 } & Low & $11.7^{* * *}$ & $10.8^{* * *}$ & $12.3^{* * *}$ & $3.3 *$ & $4.5^{* * *}$ & $6.2^{\mathrm{ns}}$ \\
\hline & High & $16.4 \mathrm{~b}$ & $19.0 \mathrm{a}$ & 22.6 & $3.9 \mathrm{~b}$ & $7.3 \mathrm{a}$ & $5.9 \mathrm{a}$ \\
\hline \multirow{2}{*}{$\mathrm{T} 4$} & Low & - & - & - & - & - & - \\
\hline & High & $20.5 \mathrm{a}$ & $20.0 \mathrm{a}$ & 22.3 & $5.0 \mathrm{a}$ & $7.8 \mathrm{a}$ & $5.9 \mathrm{a}$ \\
\hline Interaction & & * & $* *$ & ns & * & $* * *$ & $* *$ \\
\hline \multirow{2}{*}{ Treatment } & \multirow{2}{*}{ Crop Load } & \multicolumn{3}{|c|}{ Average Cluster Weight (g) } & \multicolumn{3}{|c|}{ Average Berry Weight (g) } \\
\hline & & 2009 & 2010 & 2011 & 2009 & 2010 & 2011 \\
\hline \multirow{2}{*}{$\begin{array}{l}\text { Irrigation } \\
\text { Crop Load }\end{array}$} & & $* * *$ & $* * *$ & $* * *$ & ns & ns & ns \\
\hline & & $* * *$ & $* * *$ & $* * *$ & $* *$ & ns & ns \\
\hline \multirow{2}{*}{$\mathrm{T} 1$} & Low & $242.8^{* * *}$ & $343.7^{* * *}$ & $313.9^{* * *}$ & $1.8^{\mathrm{ns}}$ & $1.9^{\mathrm{ns}}$ & $1.9^{\mathrm{ns}}$ \\
\hline & High & $162.3 \mathrm{~b}$ & $267.1 \mathrm{c}$ & $221.7 \mathrm{c}$ & 2.1 & 1.7 & 1.9 \\
\hline \multirow{2}{*}{$\mathrm{T} 2$} & Low & $294.0 * * *$ & $419.7^{* * *}$ & $534.9^{* * *}$ & $1.6^{* *}$ & $1.9^{\mathrm{ns}}$ & $2.0^{\mathrm{ns}}$ \\
\hline & High & $232.8 \mathrm{a}$ & $345.6 \mathrm{~b}$ & $303.4 \mathrm{a}$ & 2.1 & 1.9 & 2.0 \\
\hline \multirow{2}{*}{$\mathrm{T} 3$} & Low & $284.8^{* * *}$ & $423.2^{\mathrm{ns}}$ & $506.9^{* * *}$ & $1.8^{\mathrm{ns}}$ & $1.9^{\mathrm{ns}}$ & $2.0^{\mathrm{ns}}$ \\
\hline & High & $234.5 \mathrm{a}$ & $382.5 \mathrm{ab}$ & $259.8 \mathrm{~b}$ & 1.9 & 1.9 & 2.1 \\
\hline \multirow[b]{2}{*}{$\mathrm{T} 4$} & Low & - & - & - & - & - & - \\
\hline & High & $247.5 \mathrm{a}$ & $393.0 \mathrm{a}$ & $264.7 \mathrm{~b}$ & 2.0 & 1.8 & 2.1 \\
\hline Interaction & & ns & ns & $* * *$ & ns & ns & $\mathrm{ns}$ \\
\hline
\end{tabular}

For the Tukey test, different letters within the same column indicate significant differences between irrigation treatments for $p<0.05 . *$, **,

***, indicate significant differences for $p<0.05, p<0.01$, and $p<0.001$, respectively; ns, not significant.

In high-load irrigation treatments, the number of clusters per vine increased in 2011, matching each other, with the most significant increase taking place in T1 from 15.4 clusters per vine in 2009 to 21.9 clusters per vine in 2011, whereas in T4, year-on-year differences were less than two clusters per vine. The effect of irrigation treatment on this component was different in the other two years. In both cases, the treatments can be grouped in pairs: in 2009, T1 and T3 had fewer clusters than T2 and T4, and in 2010, the differences were established between the treatments that had no water input in pre-veraison (T1) or reduced water input (T2) and the treatments with the most irrigation in this phase (T3 and T4) (Table 5). 
Average cluster weight was higher in 2010, in all treatments, due to a higher number of berries per cluster, and in 2009, the clusters were less heavy even in the most irrigated treatment. In 2009, cluster weight was only differentiated in T1, which was lower than the rest of the treatments. In 2010, T1 and T4 had the lowest and highest cluster weight, respectively, with T2 and T3 remaining equal with medium weight. However, in 2011, T2 had a higher cluster weight, surpassing T4 (Table 5).

In all years, T1 was the least productive treatment, ranging from 2.6 to $4.8 \mathrm{~kg} / \mathrm{vine}$ in high load, and T4 was the most productive with yields between 5.0 and $7.8 \mathrm{~kg} / \mathrm{vine}$. The RDI treatments (T2 and T3) had intermediate yields, and in 2010, T3 was equal to T4, coinciding in high cluster load and high average berry weight (Table 5).

Load level resulted in significant differences in yield components, as the number of clusters per vine was reduced (concerning high load) and matched (between low load irrigation treatments). Production decreased with cluster thinning, except in 2011, when there were no yield differences per vine. This lack of difference was due to the incidence of phytopathogenic fungi that affected more clusters of treatments with high load. In 2009, there was a tendency for berry average weight to decrease in the low load treatments, although the differences only became significant in T2. In the following two years, there was no effect of load level on this component. The reduction in average berry weight was due to a higher number of berries per cluster, as can be deduced from the higher cluster weight (Table 5).

\subsection{Must Characteristics}

Irrigation treatment had an apparent effect on TSS in the three years of the trial, although the same harvesting criteria were established. In 2009, the severe stress supported by $\mathrm{T} 1$ limited the accumulation of sugars, while in the following two years, the results were variable (Table 6).

Acidity was similar among irrigation treatments throughout the study, except for 2009 when it was lower in T2 (Table 6). The pH was similar between years and between treatments, with lower values in T4 in relation to T2 and T3 during 2009 and 2011, while T1 showed similar values in 2009 and higher values in 2011 than those observed in T4 (Table 6). As for the compounds responsible for color, determined as total polyphenols index (TPI) and anthocyanins, irrigation had a significant effect in 2009 and 2011. In the driest year (2009), the highest irrigation dose of T4 increased the concentrations of these compounds, while in 2011, the highest values were obtained in T1 (Table 6).

Crop load adjustment by early cluster thinning increased TPI and anthocyanins in 2009 and 2010. However, crop load reduction only increased TSS and lowered pH in 2010 (Table 6). Finally, reducing the crop load increased titratable acidity in 2009 and 2011 (Table 6).

As can be seen in Table 6, there was an interaction between irrigation and crop load in the TSS in the first two years, in which cluster thinning increased the concentration of TSS in the treatments with the highest level of stress during post-veraison, whereas this effect was not observed in the year with the highest water availability. Titratable acidity presented an interaction between irrigation and crop load in the first year of study. However, when analyzing the interaction between irrigation and crop load for $\mathrm{pH}$, TPI and anthocyanins, no interactions were observed, except in 2011 for TPI and anthocyanins, due to the reduction effect of cluster thinning on these parameters in the dry season (Table 6). 
Table 6. Must characteristics, total soluble solids (TSS), titratable acidity (TA), total polyphenol index (TPI), and anthocyanins determined on fresh weight and $\mathrm{pH}$ in the years 2009, 2010, and 2011.

\begin{tabular}{|c|c|c|c|c|c|c|c|}
\hline \multirow{2}{*}{ Treatments } & \multirow{2}{*}{ Crop Load } & \multicolumn{3}{|c|}{ TSS ( ${ }^{\circ}$ Brix) } & \multicolumn{3}{|c|}{ TA (g/L) } \\
\hline & & 2009 & 2010 & 2011 & 2009 & 2010 & 2011 \\
\hline \multirow{2}{*}{\multicolumn{2}{|c|}{$\begin{array}{l}\text { Irrigation } \\
\text { Crop Load }\end{array}$}} & $* *$ & $* * *$ & * & * & ns & $\mathrm{ns}$ \\
\hline & & ns & $* * *$ & ns & $* * *$ & ns & $*$ \\
\hline \multirow{2}{*}{$\mathrm{T} 1$} & Low & $23.7^{* * *}$ & $25.7^{* * *}$ & $24.4^{\mathrm{ns}}$ & $4.1^{*}$ & $4.8^{\mathrm{ns}}$ & $5.2^{\mathrm{ns}}$ \\
\hline & High & $22.9 \mathrm{~b}$ & $22.9 \mathrm{~b}$ & $24.0 \mathrm{a}$ & $3.6 \mathrm{ab}$ & 4.7 & 4.9 \\
\hline \multirow[b]{2}{*}{$\mathrm{T} 2$} & Low & $23.0 * *$ & $24.4^{\mathrm{ns}}$ & $22.7^{\mathrm{ns}}$ & $4.3^{* * *}$ & $4.9^{\mathrm{ns}}$ & $5.1^{\mathrm{ns}}$ \\
\hline & High & $23.8 \mathrm{a}$ & $24.2 \mathrm{a}$ & $22.9 \mathrm{~b}$ & $3.3 \mathrm{~b}$ & 4.8 & 4.6 \\
\hline \multirow{2}{*}{$\mathrm{T} 3$} & Low & $24.0^{\mathrm{ns}}$ & $24.0^{* *}$ & $22.9^{* *}$ & $5.0^{* * *}$ & $5.0^{\mathrm{ns}}$ & $5.3^{\mathrm{ns}}$ \\
\hline & High & $23.8 \mathrm{a}$ & $23.2 \mathrm{~b}$ & $23.7 \mathrm{ab}$ & $3.7 \mathrm{ab}$ & 5.1 & 4.9 \\
\hline \multirow{2}{*}{$\mathrm{T} 4$} & Low & - & - & - & - & - & - \\
\hline & High & $23.5 a b$ & $23.0 \mathrm{~b}$ & $23.2 \mathrm{ab}$ & $4.1 \mathrm{a}$ & 4.8 & 5.2 \\
\hline \multicolumn{2}{|l|}{ Interaction } & $* *$ & $* * *$ & ns & $* *$ & $\mathrm{~ns}$ & ns \\
\hline \multirow{2}{*}{ Treatments } & \multirow{2}{*}{ Crop Load } & \multicolumn{3}{|c|}{ TPI (mg/g) } & \multicolumn{3}{|c|}{ Anthocyanins (mg/g) } \\
\hline & & 2009 & 2010 & 2011 & 2009 & 2010 & 2011 \\
\hline \multirow{2}{*}{\multicolumn{2}{|c|}{$\begin{array}{l}\text { Irrigation } \\
\text { Crop Load }\end{array}$}} & $* *$ & ns & $* *$ & $* *$ & ns & $* *$ \\
\hline & & $* * *$ & $* *$ & ns & $* *$ & $* *$ & ns \\
\hline \multirow{2}{*}{$\mathrm{T} 1$} & Low & $1.81^{* *}$ & $1.95^{\mathrm{ns}}$ & $1.17^{* *}$ & $1.24^{* *}$ & $0.75^{\mathrm{ns}}$ & $0.47^{*}$ \\
\hline & High & $1.08 \mathrm{~b}$ & 1.86 & $1.61 \mathrm{a}$ & $0.81 \mathrm{~b}$ & 0.69 & $0.66 \mathrm{a}$ \\
\hline \multirow[b]{2}{*}{$\mathrm{T} 2$} & Low & $1.75^{\mathrm{ns}}$ & $1.90^{\mathrm{ns}}$ & $1.39 \mathrm{~ns}$ & $1.21^{\mathrm{ns}}$ & $0.78^{\mathrm{ns}}$ & $0.51^{\mathrm{ns}}$ \\
\hline & High & $1.54 \mathrm{a}$ & 1.66 & $1.31 \mathrm{~b}$ & $1.10 \mathrm{a}$ & 0.70 & $0.49 \mathrm{~b}$ \\
\hline \multirow{2}{*}{ T3 } & Low & $1.56^{\mathrm{ns}}$ & $2.16^{* * *}$ & $1.48^{\mathrm{ns}}$ & $1.07^{\mathrm{ns}}$ & $0.83^{* *}$ & 0.60 ** \\
\hline & High & $1.21 \mathrm{ab}$ & 1.70 & $1.34 \mathrm{~b}$ & $0.87 \mathrm{ab}$ & 0.64 & $0.47 \mathrm{~b}$ \\
\hline \multirow{2}{*}{$\mathrm{T} 4$} & Low & - & - & - & - & - & - \\
\hline & High & $1.47 \mathrm{a}$ & 1.82 & $1.35 \mathrm{~b}$ & $1.14 \mathrm{a}$ & 0.77 & $0.54 \mathrm{ab}$ \\
\hline Interaction & & ns & ns & $* *$ & ns & ns & $* *$ \\
\hline \multirow{2}{*}{ Treatments } & \multirow{2}{*}{ Crop Load } & & $\mathrm{pH}$ & & & & \\
\hline & & 2009 & 2010 & 2011 & & & \\
\hline \multirow{2}{*}{\multicolumn{2}{|c|}{$\begin{array}{l}\text { Irrigation } \\
\text { Crop Load }\end{array}$}} & $* *$ & ns & $*$ & & & \\
\hline & & ns & $* *$ & ns & & & \\
\hline \multirow[b]{2}{*}{$\mathrm{T} 1$} & Low & $3.79 \mathrm{~ns}$ & $3.79 \mathrm{~ns}$ & $3.80^{\mathrm{ns}}$ & & & \\
\hline & High & $3.82 \mathrm{~b}$ & 3.82 & $3.84 \mathrm{a}$ & & & \\
\hline \multirow{2}{*}{$\mathrm{T} 2$} & Low & $3.97^{\mathrm{ns}}$ & $3.79 * * *$ & $3.71 *$ & & & \\
\hline & High & $3.93 \mathrm{a}$ & 3.94 & $3.78 \mathrm{ab}$ & & & \\
\hline \multirow{2}{*}{$\mathrm{T} 3$} & Low & $3.98^{\mathrm{ns}}$ & $3.81^{\mathrm{ns}}$ & $3.70^{\mathrm{ns}}$ & & & \\
\hline & High & $3.94 \mathrm{a}$ & 3.86 & $3.73 \mathrm{ab}$ & & & \\
\hline \multirow{2}{*}{$\mathrm{T} 4$} & Low & - & - & - & & & \\
\hline & High & $3.81 \mathrm{~b}$ & 3.81 & $3.69 \mathrm{~b}$ & & & \\
\hline Interaction & & ns & ns & ns & & & \\
\hline
\end{tabular}

For the Tukey test, different letters within the same column indicate significant differences between irrigation treatments for $p<0.05 . * * *$

***, indicate significant differences for $p<0.05, p<0.01$, and $p<0.001$, respectively; ns, not significant.

\subsection{Effect of Irrigation Treatments on Dry Matter Production}

Although the irrigation treatment affected the global production of biomass, the response was conditioned by the year's characteristics and the type of organ considered. In 2011, there were no differences in any case, and 2009 was the year in which biomass production per vine was lowest (Table 7). In the three years under study, the T1 and T4 treatments were the ones with the lowest and highest dry matter in vegetation, respectively, and the RDI treatments, with similar values between them, were located between both, although these differences were significant only in 2009 (Table 7). Concerning clusters, 
irrigation increased the accumulated dry matter, although the differences between the irrigated treatments were not significant (Table 7).

Table 7. Total dry matter production, vegetative (clipping + pruning) and productive (harvest), for the different high load irrigation treatments, in the years 2009, 2010, and 2011.

\begin{tabular}{|c|c|c|c|c|c|c|c|c|c|}
\hline \multicolumn{10}{|c|}{ Dry Matter Production } \\
\hline \multirow{2}{*}{ Treatment } & \multicolumn{3}{|c|}{ Vegetative (g/vine) } & \multicolumn{3}{|c|}{ Productive (g/vine) } & \multicolumn{3}{|c|}{ Total (g/vine) } \\
\hline & 2009 & 2010 & 2011 & 2009 & 2010 & 2011 & 2009 & 2010 & 2011 \\
\hline Irrigation & $* * *$ & ns & ns & ** & * & ns & $* * *$ & * & ns \\
\hline $\mathrm{T} 1$ & $259 c$ & $438 \mathrm{a}$ & $544 \mathrm{a}$ & $746 \mathrm{~b}$ & $1259 \mathrm{~b}$ & 1445 a & 1005 c & $1696 \mathrm{~b}$ & 1989 a \\
\hline $\mathrm{T} 2$ & $43 \mathrm{bc}$ & $540 \mathrm{a}$ & $599 a$ & $1311 \mathrm{a}$ & $1710 \mathrm{ab}$ & 1948 a & $1744 \mathrm{ab}$ & $2250 \mathrm{ab}$ & $2547 \mathrm{a}$ \\
\hline T3 & $468 \mathrm{~b}$ & $574 \mathrm{a}$ & $548 \mathrm{a}$ & $1124 \mathrm{ab}$ & 2229 a & $1752 \mathrm{a}$ & 1592 b & $2803 a b$ & $2300 \mathrm{a}$ \\
\hline $\mathrm{T} 4$ & $744 \mathrm{a}$ & $654 \mathrm{a}$ & $612 \mathrm{a}$ & $1515 \mathrm{a}$ & 2269 a & $1751 \mathrm{a}$ & 2259 a & 2923 a & $2363 \mathrm{a}$ \\
\hline
\end{tabular}

For the Tukey test, different letters within the same column indicate significant differences between irrigation treatments for $p<0.05 . *$,**, $* * *$, indicate significant differences for $p<0.05, p<0.01$, and $p<0.001$, respectively; ns, not significant.

The average yield of material in the vineyard's aerial organs for the three years of the trial ranged from $2515 \mathrm{~g}$ for T4 to $1563 \mathrm{~g}$ for T1. Of this biomass, around $25 \%$ corresponded to vegetative organs and $75 \%$ to clusters.

Figure 3 shows the relationship between average $\psi_{\mathrm{s}}{ }^{\mathrm{md}}$ for the full crop cycle (including post-harvest) and dry matter production. As shown in this figure, biomass production decreases linearly as the stress supported by the vine increases. The adjustment is highly significant in all cases, with a coefficient of determination $\left(R^{2}\right)$ greater than 0.72 , improving to 0.85 when considering only the vegetative organs, and with an $R^{2}$ of 0.73 in the case of clusters.

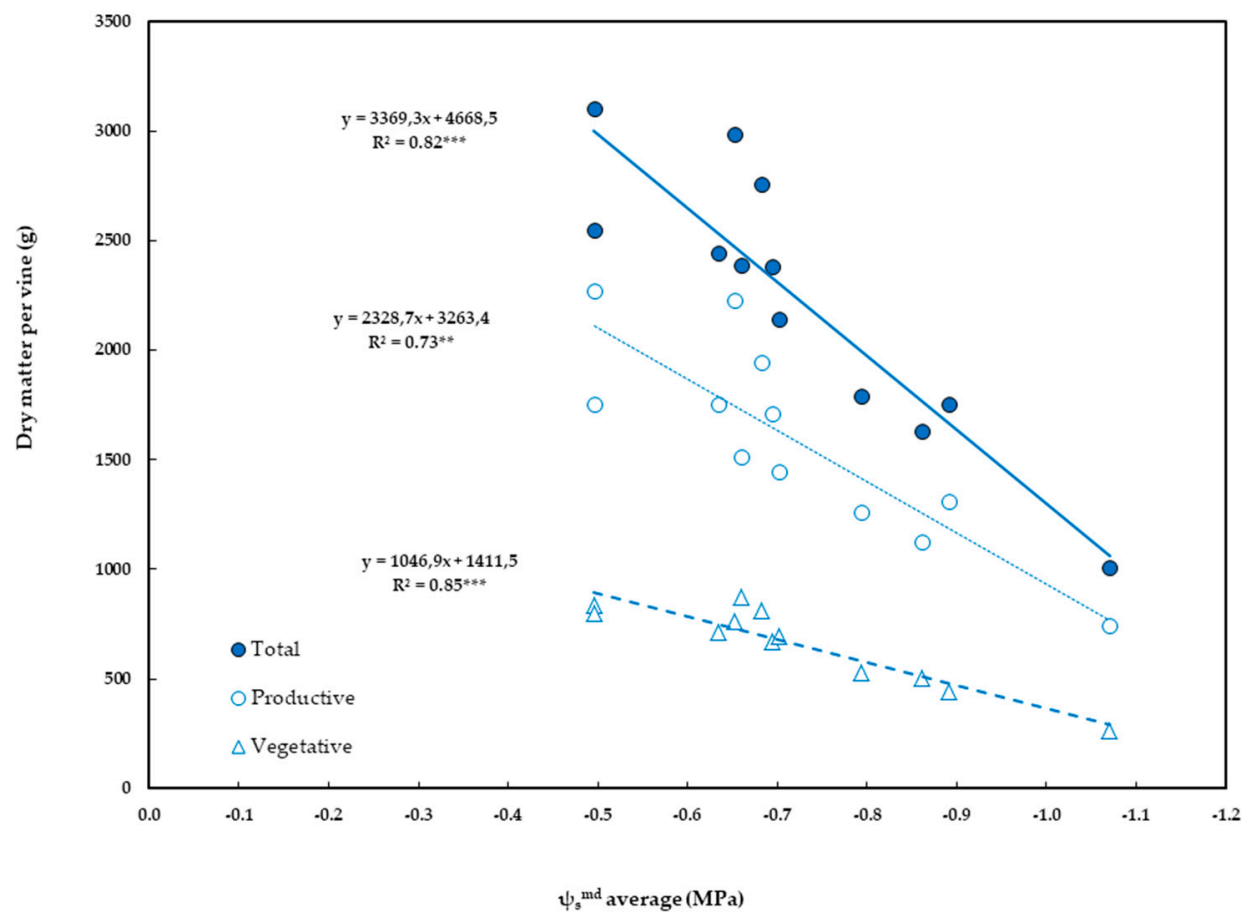

Figure 3. Relationship between the average value for the whole crop cycle of stem water potential measured at midday and total dry matter production (g/vine) and broken down into dry matter of bunches (productive) and dry matter of the vegetative organs (vegetative). ${ }^{* *}, * * *$ indicates a significance at $p<0.01$ and $p<0.001$, respectively.

If the relationship with dry matter production is established with the radiation intercepted by the plant per square meter of soil surface throughout the crop cycle rather than 
with the water status (Figure 4), the fit remains linear and significant, with intercepted radiation increasing with biomass production, but significant only when considering the vegetative organs, with $R^{2}=0.57$.

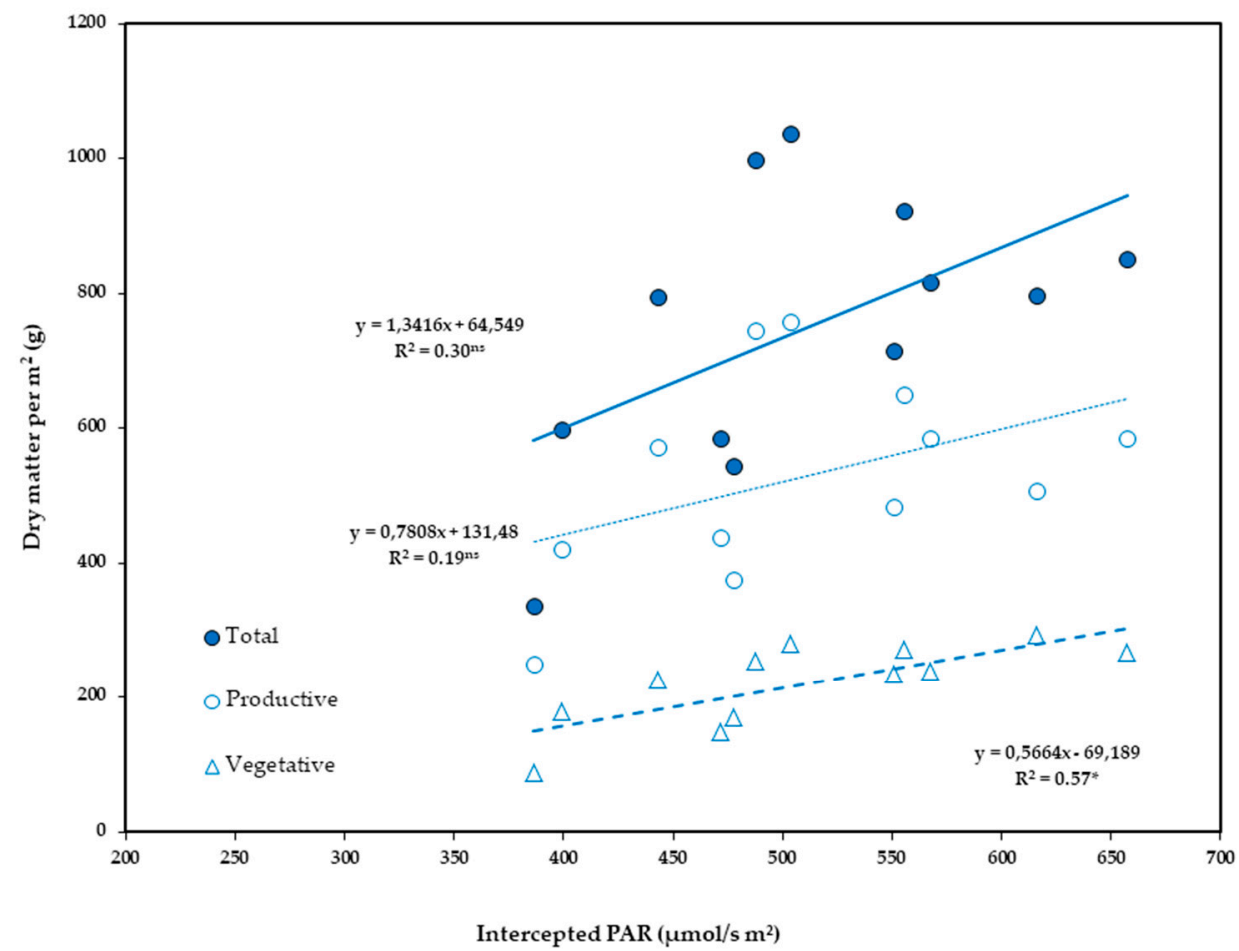

Figure 4. Relationship between seasonal PAR radiation intercepted by the vineyard (RI) and Total dry matter production $\left(\mathrm{g} / \mathrm{m}^{2}\right)$, broken down into Productive dry matter and Vegetative dry matter. * indicates significance at $p<0.05 ;$ ns, not significant.

When analyzing the WP of the three years jointly, the low efficiency of 2009 in relation to the following years stands out, showing the importance of the effect of the precipitations prior to the beginning of the crop cycle. As a consequence of the balance between water received by the crop and biomass production, RDI treatments (T2 and T3) were more productive in the use of water with respect to the more irrigated treatment (T4) (Table 8). When comparing deficit irrigation treatments, in two of the three years, T3 had a tendency towards higher WP values, both in the vegetative and productive components, although the differences were not significant (Table 8). In 2009, the early start of the irrigation season increased the volume of irrigation water in T3, reducing the WP in relation to T2 (Table 8).

Table 8. Water productivity of vegetation (WPv) and production (WPp) of the different high load irrigation treatments, corresponding to the years 2009, 2010, and 2011.

\begin{tabular}{ccccccccc}
\hline & \multicolumn{2}{c}{2009} & \multicolumn{2}{c}{2010} & \multicolumn{2}{c}{2011} & \multicolumn{2}{c}{ 2009-2011 } \\
\hline Treatment & WPp & WPv & WPp & WPv & WPp & WPv & WPp & WPv \\
\hline Irrigation & $* * *$ & ns & $* *$ & $*$ & $* *$ & $*$ & $* * *$ & $* * *$ \\
\hline T2 & $4.68 \mathrm{a}$ & $0.47 \mathrm{a}$ & $7.20 \mathrm{ab}$ & $0.85 \mathrm{ab}$ & $6.96 \mathrm{a}$ & $0.87 \mathrm{ab}$ & $6.28 \mathrm{a}$ & $0.73 \mathrm{ab}$ \\
T3 & $3.88 \mathrm{a}$ & $0.52 \mathrm{a}$ & $10.38 \mathrm{a}$ & $1.06 \mathrm{a}$ & $9.25 \mathrm{a}$ & $1.09 \mathrm{a}$ & $7.84 \mathrm{a}$ & $0.89 \mathrm{a}$ \\
T4 & $2.75 \mathrm{~b}$ & $0.48 \mathrm{a}$ & $4.11 \mathrm{~b}$ & $0.45 \mathrm{~b}$ & $3.71 \mathrm{~b}$ & $0.51 \mathrm{~b}$ & $3.52 \mathrm{~b}$ & $0.48 \mathrm{~b}$
\end{tabular}

For the Tukey test, different letters within the same column indicate significant differences between irrigation treatments for $p<0.05 .{ }^{*}, * * * * *$, indicate significant differences for $p<0.05, p<0.01$, and $p<0.001$, respectively; ns, not significant. 


\subsection{Relationship between Vine Water Status and Productivity and Must Characteristics}

To analyze how water status affected productivity, Figure 5 shows the relationship between the average $\psi_{\mathrm{s}}{ }^{\mathrm{md}}$ value of the different treatments and periods (pre-veraison, post-veraison, total), with the different components of yield in the three years under study.
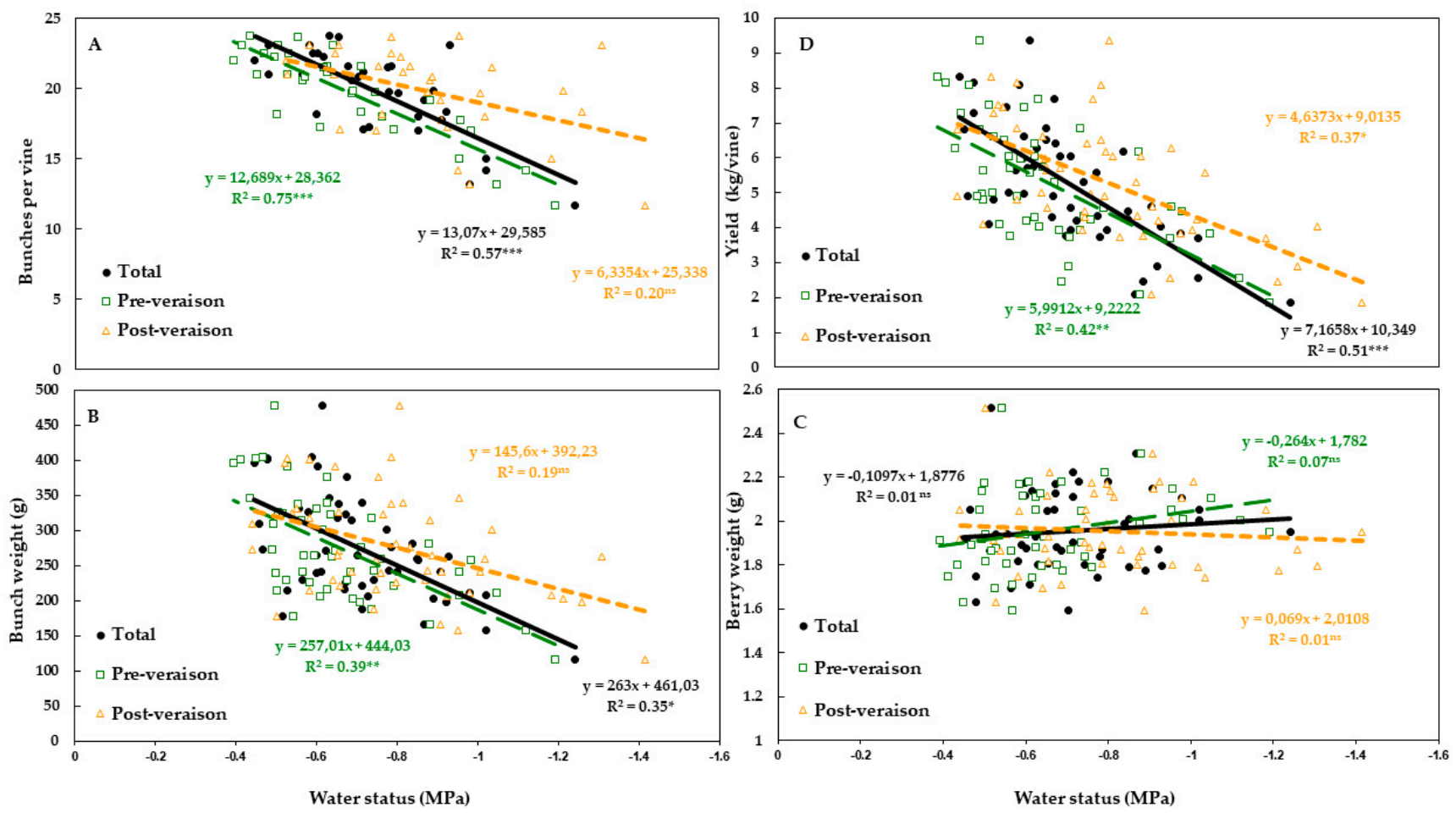

Figure 5. Relationships between annual water status, in pre-veraison and post-veraison, of the high load treatments, with production parameters: number of bunches per vine (A), fresh bunch weight (g) (B), fresh berry weight (g) (C), and yield in fresh weight (kg/vine) (D). In the case of the number of clusters, this was compared with the previous year's water status. *, $* *, * *$, indicate that the factor was significant at $p<0.05, p<0.01$, and $p<0.001$, respectively; ns, not significant.

In the case of the number of clusters per vine, the relationship was established with the previous year's water status. The number of clusters per vine decreased linearly as the severity of water stress increased from the previous season (Figure 5A), obtaining the most robust relationship with the pre-veraison period of $R^{2}=0.75$. At the same time, it was not significant when considering water status during the post-veraison period. It was, however, significant when considering both periods together, although $\mathrm{R}^{2}$ decreased in relation to pre-veraison (Figure 5A).

With respect to cluster weight, it showed a closer relationship with the pre-veraison water status than with the post-veraison or complete cycle, as the number of set berries per cluster increased (Figure 5B), since berry size remained constant between treatments and years, with no relationship with water status (Figure 5C).

Vine yield decreased with $\psi_{\mathrm{s}}{ }^{\mathrm{md}}$ measured until harvest, with an $\mathrm{R}^{2}$ of 0.51 , while $\mathrm{R}^{2}$ was worse when considering pre-veraison or post-veraison separately $\left(R^{2}=0.42\right.$ and 0.36 , respectively) (Figure 5D).

The relationships between vine water status, determined by the average value of $\psi_{\mathrm{s}}{ }^{\mathrm{md}}$ of the different irrigation treatments at high load, in different periods (pre-veraison, post-veraison, total), with the different quality parameters considered in the three years under study are presented in Table 9. A significant relationship with water status was only obtained in the case of acidity and potassium content. As vine water status improved, total acidity increased, with malic acid the main cause. The pre-veraison water status had the most significant effect on this parameter (Table 9). The potassium concentration also 
increased as vine water status improved, but in this case, in post-veraison $\left(R^{2}=0.33\right)$, with the other two periods studied not being significant (Table 9).

Table 9. Relationships between annual water status (Total), in pre-veraison and post-veraison, of the high load treatments, and quality parameters, using a linear function.

\begin{tabular}{|c|c|c|c|c|c|c|}
\hline \multirow{2}{*}{ Parameters } & \multicolumn{3}{|c|}{$\mathbf{a}$} & \multicolumn{3}{|c|}{$\mathbf{b}$} \\
\hline & Total & Pre-Veraison & Post-Veraison & Total & Pre-Veraison & Post-Veraison \\
\hline TSS & 0.1262 & 0.3686 & 0.0835 & 23.519 & 23.672 & 23.362 \\
\hline $\mathrm{pH}$ & -0.1987 & -0.1301 & -0.1597 & 3.6907 & 3.7456 & 3.7027 \\
\hline Total Acidity & 2.7001 & 2.5713 & 1.5254 & 6.3846 & 6.1659 & 5.703 \\
\hline Tartaric Acid & -0.8517 & -0.9691 & -0.3747 & 4.947 & 4.9122 & 5.2475 \\
\hline Malic Acid & 1.4232 & 1.2826 & 0.8406 & 2.6781 & 2.5151 & 2.3482 \\
\hline Potassium & 2.8501 & 1.7132 & 2.3912 & 3.6652 & 2.777 & 3.573 \\
\hline TPI & 0.7085 & 0.8246 & 0.2965 & 1.9954 & 2.0365 & 1.7331 \\
\hline Anthocyanins & -0.3557 & -0.3248 & -0.2207 & 0.4978 & 0.5358 & 0.5717 \\
\hline \multirow{2}{*}{ Parameters } & \multicolumn{3}{|c|}{$\mathbf{R}^{2}$} & \multicolumn{3}{|c|}{ Significance } \\
\hline & Total & Pre-Veraison & Post-Veraison & Total & Pre-Veraison & Post-Veraison \\
\hline TSS & 0.00 & 0.01 & 0.00 & ns & ns & ns \\
\hline $\mathrm{pH}$ & 0.09 & 0.04 & 0.10 & ns & ns & ns \\
\hline Total Acidity & 0.43 & 0.46 & 0.24 & $*$ & $* *$ & ns \\
\hline Tartaric Acid & 0.04 & 0.06 & 0.01 & ns & ns & ns \\
\hline Malic Acid & 0.34 & 0.33 & 0.21 & $*$ & $*$ & ns \\
\hline Potassium & 0.27 & 0.12 & 0.33 & ns & ns & * \\
\hline TPI & 0.10 & 0.16 & 0.03 & ns & ns & ns \\
\hline Anthocyanins & 0.05 & 0.04 & 0.03 & ns & ns & ns \\
\hline
\end{tabular}

a (slope), $\mathrm{b}$ (ordered at origin). ${ }^{*}, * *$, indicate that the factor was significant at $p<0.05$ and $p<0.01$, respectively; ns, not significant.

\section{Discussions}

In the cultivation of vineyards for winemaking, the value of the harvest is determined by the production/quality binomial so that, as in other fruit production, lower yield production systems or costly cultivation practices can be adopted to enhance aspects that give greater value to the final product. However, this quality is marked by a complex set of factors that can interact with each other. Agro-climatic conditions are decisive for berry composition, as are cultural practices. It is this complicated situation that causes the disparity of results that can be found in the literature when the effect of practices such as irrigation or cluster thinning on the production and quality of a vineyard is analyzed, and that justifies the need to adapt cultural practices to specific growing conditions with a medium-term vision. This work aimed to analyze the response of a cv. Tempranillo vineyard to different irrigation strategies and cluster loading in the Guadiana Valley's growing conditions, in southwestern Spain.

A determining aspect of the results obtained was the year's characteristics, both in terms of weather conditions and the "memory" of the vineyard. Under these conditions, the response of the water status of the vines to the irrigation treatments was variable, with irrigation dose interacting with the characteristics of the year despite establishing the irrigation criteria (start of irrigation and changes in veraison) according to $\psi_{\mathrm{s}}{ }^{\mathrm{md}}$ levels and calculating the doses according to water consumption $\left(\mathrm{ET}_{\mathrm{c}}\right)$. It was possible to establish different levels of water stress in the pre-veraison and post-veraison periods in RDI treatments.

The average water needs of the vineyard obtained in this study were $568 \mathrm{~mm}$, allowing the RDI strategies to save irrigation water between 70 and $62 \%$, while this same vineyard, in the period 2005-2008 [42], presented very variable water needs between years, with an average value of $500 \mathrm{~mm}$ and promoting the management of sustained deficit irrigation, water reductions according to the percentages applied. 
The production cycle duration was variable between years, faster in the driest year with less accumulation of DD from budbreak to harvest, coinciding with lower crop load. These results also show an acceleration of ripening due to cluster thinning, which is in agreement with the findings of authors such as [21,47].

In this study, vine water status was not affected by crop load. A similar result was found for cv. Tempranillo by [42] and for cv. Cabernet Sauvignon by [41], although cluster thinning was carried out in veraison in both cases. However, [60] found that reducing crop load on Thomson Seedless improved water status, so there seems to be a lack of consensus regarding the effect of cluster thinning on water status.

Figure 2 shows a strong parallelism between the seasonal evolution of $\psi_{\mathrm{s}}{ }^{\mathrm{md}}$ in the dry treatment and $\mathrm{ET}_{\mathrm{O}}$ over the three years of the trial, indicating a high degree of coupling between the two. These results question the isohydric behavior in vines [3,61,62], which was put forward as an argument to question the validity of the $\psi_{\mathrm{s}}{ }^{\text {md }}$ measure as an indicator of water status in this crop $[63,64]$. This controversy regarding isohydric or anisohydric behavior in the vine may be due to the influence of multiple factors as found by several authors $[4,62,65-68]$.

A positive response was found in terms of the relationship between dry matter production and PAR radiation intercepted by the crop. As the interception of PAR radiation increased, an increase in dry matter production was observed (Figure 4), obtaining low coefficients of determination, both for total dry matter and productive dry matter, in line with the results obtained for cv. Tempranillo by [69]. The correlation with vegetative organ biomass was higher, coinciding with the results of [70] in which it was reported that several factors affect the relationship between dry matter production and intercepted PAR radiation. In this study, shoot clipping carried out to maintain the vegetation in a vertical position and facilitate the passage of machinery contained the vegetation and reduced the intercepted PAR radiation with greater intensity in the treatments with less water stress. This could distort the correlation between dry matter and intercepted PAR radiation. Given these results, it is clear that the use of irrigation strategies requires adapted cultivation techniques that do not limit their potential, such as forming plants with free vegetation or increases in the height of the vegetation, which have demonstrated a greater capacity for intercepting radiation [71].

The results obtained confirm that water deficit reduces vineyard productivity in terms of both grape fresh weight (Table 5), as well as the production of vegetative and reproductive biomass (Table 7 and Figure 3), which is in accordance with previous works by other authors [8,72]. The effect was more evident in the vegetative organs, since, as pointed out in $[73,74]$, water stress primarily affects cell expansion and, therefore, vegetative growth, and, at more severe levels, cell multiplication and photosynthesis. The RDI strategies tested resulted in yield losses, unlike the results obtained in other woody crops under similar agro-climatic conditions [75]. On the other hand, the strategy with the best yields was that which in each year managed to maintain the best vine water status throughout the crop (Figure 5). Evidence has been obtained that early stress after budbreak was detrimental to production, both in the current and the following year (Figure 5) [42,76-78]. This is due to the decrease in bud fertility (Figure 5A) caused by the stress of the previous year at the time of fruit bud initiation and differentiation [73] and a decrease in berry set due to stress in the current year (Figure 5B), thus reducing cluster weight $[10,79]$. Irrigation treatment did not modify berry size (Table 5), unlike the results obtained in other studies [26,80], probably because in no year did the berry reach a sufficiently severe stress level during the three weeks after flowering, which according to [81], is when the potential size of the berry is determined.

Early cluster thinning decreased yield (Table 5), although this was slightly compensated for by increased cluster weight due to a higher number of berries per cluster, as individual berry weight was not significantly modified.

The effect of irrigation treatment on grape quality was very variable between years (Table 6), as also previously noted [26], no clear effect was found in this study (2009-2011), 
nor in previous studies carried out on the same vineyard (2005-2008) [42,47]. Considering that the greatest differences between irrigation treatments were found in 2009 (Table 6), it is evident that it is necessary to generate notable differences in vine water status to affect the characteristics measured at harvest.

The establishment of different water statuses in the different phases of the crop, favored by irrigation management, did not imply a significant decrease in the concentration of soluble solids (Table 9). This concurs with the results obtained for cv. Tempranillo by authors such as $[82,83]$ but differs from those obtained by [84] who found a relationship between water status and TSS, which increased with the water stress integral. These results are explained by the fact that no stress levels were reached in this study that compromised berry size, and so it was not possible to establish differential soluble solids concentrations [85].

As for must total acidity, the improvement observed in water status was observed to be correlated with the increase in total acidity, with a good correlation being obtained for the average of the whole period but which was more conditioned by the water status in the preveraison period (Table 9). When breaking down this total acidity into its main components (malic and tartaric acid), it can be observed that this increase was more influenced by an increase in malic acid, mostly affected by the supported pre-veraison water status (Table 9). This result, also reported by other authors [82,83], may be due to irrigation increasing vegetative growth $[86,87]$ resulting in a more unfavorable microclimate for malic acid combustion, with vegetative growth closely related to must malic acid content [26]. For its part, tartaric acid content remained very stable, regardless of water status, which is in agreement with results obtained for $\mathrm{cv}$. Tempranillo by other authors $[82,83]$. The above leads to a decrease in the tartrate-malate ratio as the water status improves [83]; a relationship that can have a major impact on the final $\mathrm{pH}$ of the wine due to the greater presence of a weak acid (the malic acid) against a strong acid (the tartaric acid).

As for the effect of irrigation on $\mathrm{pH}$, the results support the variability obtained by other authors. An apparent effect was observed in 2009, but there was no effect of irrigation in 2010, as previously observed [42], or there was a decrease as the result of irrigation in 2011 (Table 6), as also observed by some authors [5,88]. Similarly, no conclusive result could be obtained when analyzing the effect of cluster thinning on this parameter.

Water stress can reduce potassium absorption due to reduced root activity and growth [89]. This is reflected in Table 9, as it can be seen that, as other authors have also found [83,90], as vine water status improves, there is an increase in must potassium content, although this correlation was only significant in this study for water status during the ripening period (post-veraison).

Color very much conditions the quality of the wine, and so the incidence that different irrigation managements can have on this parameter is of great importance. The different studies on this subject sometimes obtain contradictory results $[83,84,87,91]$. The results of this study could not establish a clear correlation between the water status supported by the vines and TPI, nor with anthocyanin content (Table 9). This somewhat demystifies the idea that irrigation and quality are opposing concepts and contradicts what has been established by other authors $[83,84]$ who did see a clear effect of irrigation on the reduction in these parameters. The small difference in quality induced by the different water regimes may be because no differences were established in berry size (Figure 5C), a parameter that is inversely correlated with polyphenolic load [84].

Cluster thinning is an expensive practice that reduces the production of the vineyard and can only be justified by a significant improvement in grape characteristics. In this sense, this work shows an increase in parameters such as acidity, soluble solids, and color compounds, although these differences were, once again, dependent on the year. Cluster thinning increased TSS when the availability of assimilates was lower, that is to say, in the treatments with higher water stress in 2009 and 2010, and even decreased in T3 in 2011 probably due to the considerable increase in cluster size caused by cluster thinning increasing the competition for assimilates between berries (Table 5). Cluster 
thinning increased anthocyanins and TPI, confirming other authors' results on this same cultivar $[47,90,92]$. As previously mentioned, when differences in yield occurred due to irrigation management, no conclusive results were obtained on must concentrations of polyphenols and anthocyanins, with a different effect to load regulation by cluster elimination, as also observed by $[91,93]$. This highlights the importance in the synthesis of compounds responsible for color of other factors such as the effective illumination of leaves and bunches [94] and the volumes of water used [95].

An important aspect of this work is the comparison of the effect produced by the different dates of cluster thinning on the same vineyard. In this study, there was an improvement in the compounds responsible for wine color in the year in which the highest production was recorded (Table 5) and the lowest vegetative development (Table 4), which can be added to the improvement found for late cluster thinning on the same vineyard by [42]. This contributed to improving the source-supply ratio due to cluster thinning, an effect that was more noticeable in early than in late cluster thinning, as also noted in [93]. On the other hand, late cluster thinning has been reported to reduce must acidity and increase $\mathrm{pH}$ [42], while, in this study, the same cluster thinning carried out earlier improved acidity in two of the years studied and decreased $\mathrm{pH}$ in one of them (Table 6). Another aspect to highlight with respect to cluster thinning was the advance in ripening that was produced, which was more marked in early thinning (13 days in this study) than was observed for late thinning (4 days) for this same vineyard by [42].

\section{Conclusions}

As can be seen in our study, vine water status is influenced by irrigation management and conditioned by the characteristics of the year, being the evolution of the water status of rainfed vines influences by the annual evolution of $\mathrm{ET}_{0}$, which gives an idea of isohydric behavior in the vine. In this sense, it could be seen as pre-veraison water status is more decisive in vine productivity, as it affects the berries' setting in the current year and bud fertility the following year. On the other hand, it was noted that crop load level, adjusted by early cluster thinning, does not affect vine water status.

Water deficit reduces vineyard yield in terms of both fresh grape weight and vegetative and reproductive biomass production. However, this water deficit due to regulated deficit irrigation is an excellent tool to increase water productivity, as this paper has shown.

About the quality of the musts, our study can conclude that the improvement in vine water status in pre-veraison increases must total acidity, mainly due to the increase in malic acid, while this improvement in vine water status after veraison leads to an increase in must potassium content.

Another point addressed in this study was the regulation of the crop load by early cluster thinning, which results in a reduction in yield, although with a compensatory effect by increasing cluster size, also producing an acceleration in ripening. Improving this crop load regulation, the source-sink ratio, especially in high production years, and improving also limiting factors for wine quality in semiarid areas, such as acidity and must color.

Given the vine's variable response to the irrigation treatments proposed in this and previous works on the same experimental vineyard, it seems more interesting not so much to talk about irrigation management but rather about the management of water stress in specific periods of the phenological cycle of the crop.

Author Contributions: L.A.M. $(\approx 45 \%)$ : literature review; planning and execution of experimental work; processing of data; discussion of results and writing of the paper. D.U. $(\approx 15 \%)$ : processing of data; discussion of results. E.V. $(\approx 10 \%)$ : processing of data. D.M. $(\approx 10 \%)$ : processing of data. M.d.H.P. $(\approx 20 \%)$ : project coordinator; planning of experimental work and revision of the paper. All authors have read and agreed to the published version of the manuscript.

Funding: This research was funded by INIA (RTA2008-00037-C04 and RTA2009-00026-C02 projects).

Acknowledgments: Junta de Extremadura (GR18196, Research Group AGA001, LOI1302020/1 and CCESAGROS projects. 
Conflicts of Interest: The authors declare no conflict of interest.

\section{References}

1. Escalona, J.M.; Flexas, J.; Medrano, H. Stomatal and non-stomatal limitations of photosynthesis under water stress in field-grown grapevines. Funct. Plant. Biol. 1999, 26, 421-433. [CrossRef]

2. Medrano, H.; Escalona, J.M.; Flexas, J. Indicadores fisiológicos para el control del estado hídrico de la vid. In Fundamentos, aplicación y consecuencias del riego en la vid; Baeza, P., Lissarrague, J.R., Sánchez, P., Eds.; Agrícola Española: Madrid, Spain, 2007; pp. 15-34.

3. Chaves, M.; Zarrouk, O.; Francisco, R.; Costa, J.M.; Santos, T.; Regalado, A.P.; Rodrigues, M.L.; Lopes, C.M. Grapevine underdeficit irrigation: Hints from physiological and molecular data. Ann. Bot. 2010, 105, 661-676. [CrossRef] [PubMed]

4. Lavoie-Lamoureux, A.; Sacco, D.; Risse, P.-A.; Lovisolo, C. Factors influencing stomatal conductance in response to water availability in grapevine: A meta-analysis. Physiol. Plant. 2017, 159, 468-482. [CrossRef] [PubMed]

5. García-Escudero, E. Influencia de la dosis y del momento de aplicación del riego sobre la producción, desarrollo vegetativo, calidad del mosto y nutrición mineral de la vid (Vitis vinifera L.). Ph.D. Thesis, Universidad Politécnica de Madrid, Madrid, Spain, 1992.

6. Junquera, P.; Lissarrague, J.R.; Jimenez, L.; Linares, R.; Baeza, P. Long-term effects of different irrigation strategies on yield components, vine vigour, and grape composition in cv. Cabernet-Sauvignon (Vitis vinifera L.). Irrig. Sci. 2012, 30, 351-361. [CrossRef]

7. Ollat, N.; Diakou-Verdin, P.; Carde, J.; Barrieu, F.; Gaudillère, J.P.; Moing, A. Grape berry development: A review. J. Int. Sci. Vigne Vin 2002, 36, 109-131.

8. Williams, L.E.; Matthews, M.A. Grapevine. In Irrigation of Agricultural Crops; Stewart, B.A., Nielsen, D.R., Eds.; Agronomy Monograph $\mathrm{n}^{\circ}$. 30; ASA-CSSA-SSSA: Madison, WI, USA, 1990; pp. 1019-1055.

9. Shellie, K.C. Vine and berry response of merlot (Vitis vinifera L.) to differential water stress. Am. J. Enol. Vitic. 2006, 57, 514-518.

10. Matthews, M.A.; Anderson, M.M.; Schultz, H.R. Phenological and growth responses to early and late season water deficits in Cabernet franc. Vitis 1987, 26, 147-160. [CrossRef]

11. Naor, A.; Bravdo, B.; Hepner, Y. Effect of Post-Veraison Irrigation Level on Sauvignon blanc Yield, Juice Quality and Water Relations. S. Afr. J. Enol. Vitic. 1993, 14, 19-25. [CrossRef]

12. Poni, S.; Lakso, A.; Turner, J.; Melious, R. Interactions of crop level and late season water stress on growth and physiology of field-grown Concord grapevines. Am. J. Enol. Vitic. 1994, 45, 252-258.

13. Ojeda, H.; Deloire, A.; Carbonneau, A.; Ageorges, A.; Romieu, C. Berry development of grapevines: Relations between the growth of berries and their DNA content indicate cell multiplication and enlargement. Vitis 1999, 38, 145-150. [CrossRef]

14. Matthews, M.A.; Nuzzo, V. Berry size and yield paradigms on grapes and wines quality. Acta Hortic. 2007, $754,423-436$. [CrossRef]

15. Baeza, P.; Conde, J.R.; Lissarrague, J.R.; Junquera, P. Agronomic and ecophysiological responses of field-grown "Cabernet Sauvignon" grapevines to three irrigation treatments. Acta Hortic. 2005, 689, 373-380. [CrossRef]

16. Basile, B.; Girona, J.; Behboudian, M.H.; Mata, M.; Rosello, J.; Ferré, M.; Marsal, J. Responses of "Chardonnay" to deficit irrigation applied at different phenological stages: Vine growth, must composition, and wine quality. Irrig. Sci. 2012, 30, 397-406. [CrossRef]

17. Ferreyra, R.; Sellés, G.; Ruiz, R.; Sellés, I. Efecto del estrés hídrico aplicado en distintos periodos de desarrollo de la vid cv. Chardonnay en la producción y calidad del vino. Agric. Técnica 2003, 63, 277-286. [CrossRef]

18. Gu, S.; Du, G.; Zoldoske, D.; Hakim, A.; Cochran, R.; Fugelsang, K.; Jorgensen, G. Effects of irrigation amount on water relations, vegetative growth, yield and fruit composition of Sauvignon blanc grapevines under partial rootzone drying and conventional irrigation in the San Joaquin Valley of California, USA. J. Hortic. Sci. Biotechnol. 2004, 79, 26-33. [CrossRef]

19. Intrigliolo, D.; Perez, D.; Risco, D.; Yeves, A.; Castel, J.R. Yield components and grape composition responses to seasonal water deficits in Tempranillo grapevines. Irrig. Sci. 2012, 30, 339-349. [CrossRef]

20. Keller, M.; Romero, P.; Gohil, H.; Smithyman, R.P.; Riley, W.R.; Casassa, L.F.; Harbertson, J.F. Deficit Irrigation Alters Grapevine Growth, Physiology, and Fruit Microclimate. Am. J. Enol. Vitic. 2016, 67, 426-435. [CrossRef]

21. Santesteban, L.; Miranda, C.; Royo, J. Regulated deficit irrigation effects on growth, yield, grape quality and individual anthocyanin composition in Vitis vinifera L. cv. 'Tempranillo'. Agric. Water Manag. 2011, 98, 1171-1179. [CrossRef]

22. Schultz, H.; Matthews, M. Vegetative Growth Distribution During Water Deficits in Vitis vinifera L. Funct. Plant. Biol. 1988, 15, 641-656. [CrossRef]

23. Uriarte, D.; Mancha, L.; Moreno, D.; Bejarano, M.; Valdes, E.; Talaverano, I.; Prieto, M.H. Effects of timing of water deficit induction on 'Doña Blanca' white grapevine under semi-arid growing conditions of south-western Spain. Acta Hortic. 2017, 1150, 493-500. [CrossRef]

24. Shellie, K. Water Productivity, Yield, and Berry Composition in Sustained versus Regulated Deficit Irrigation of Merlot Grapevines. Am. J. Enol. Vitic. 2014, 65, 197-205. [CrossRef]

25. Girona, J.; Marsal, J.; Mata, M.E.R.M.C.; Del Campo, J.; Basile, B. Phenological sensitivity of berry growth and composition of Tempranillo grapevines (Vitis viniferaL.) to water stress. Aust. J. Grape Wine Res. 2009, 15, 268-277. [CrossRef]

26. Intrigliolo, D.; Castel, J.R. Response of grapevine cv. 'Tempranillo' to timing and amount of irrigation: Water relations, vine growth, yield and berry and wine composition. Irrig. Sci. 2010, 28, 113-125. [CrossRef] 
27. Munitz, S.; Netzer, Y.; Schwartz, A. Sustained and regulated deficit irrigation of field-grown Merlot grapevines. Aust. J. Grape Wine Res. 2016, 23, 87-94. [CrossRef]

28. Uriarte, D. Efecto del riego y el nivel de carga de cosecha en cv. Tempranillo en condiciones de clima mediterráneo semi-árido. Ph.D. Thesis, Universidad de Extremadura, Badajoz, Spain, 2016.

29. Romero, P.; Fernádez-Fernádez, J.I.; Martínez-Cutillas, A. Physiological thresholds for efficient regulated deficit-irrigation management in wine grapes grown under semiarid condition. Am. J. Enol. Vitic. 2010, 61, 300-312.

30. Williams, L.; Ayars, J. Grapevine water use and the crop coefficient are linear functions of the shaded area measured beneath the canopy. Agric. Meteorol. 2005, 132, 201-211. [CrossRef]

31. Howell, G.S. Sustainable grape productivity and the growth-yield relationship: A Review. Am. J. Enol. Vitic. 2001, 52, 165-174.

32. Jackson, J.E. World-wide development of high density planting in research and practice. Acta Hortic. 1989, 243, 17-27. [CrossRef]

33. Kliewer, W.M.; Dokoozlian, N.K. Leaf area/crop weight ratios of grapevines: Influence on fruit composition and wine quality. Am. J. Enol. Vitic. 2005, 56, 170-181.

34. Monteith, J.L. Solar Radiation and Productivity in Tropical Ecosystems. J. Appl. Ecol. 1972, 9, 747. [CrossRef]

35. Poni, S.; Intrieri, C. Grapevine photosynthesis: Effects linked to light radiation and leaf age. Adv. Hort. Sci. 2001, 15, 5-15.

36. Di Profio, F.; Reynolds, A.G.; Kasimos, A. Canopy Management and Enzyme Impacts on Merlot, Cabernet franc, and Cabernet Sauvignon. I. Yield and Berry Composition. Am. J. Enol. Vitic. 2011, 62, 139-151. [CrossRef]

37. Reynolds, A.G.; Heuvel, J.E.V. Influence of grapevine training systems on vine growth and fruit composition: A Review. Am. J. Enol. Vitic. 2009, 60, 251-268.

38. Kliewer, W.M. Trellising and spacing adjust to modern needs. Calif. Agric. 1980, 34, 36-37.

39. Lopez, G.; Mata, M.; Arbones, A.; Solans, J.R.; Girona, J.; Marsal, J.; Clearwater, M.J.; Seleznyova, A.N.; Thorp, T.G.; Blattmann, P.; et al. Mitigation of effects of extreme drought during stage III of peach fruit development by summer pruning and fruit thinning. Tree Physiol. 2006, 26, 469-477. [CrossRef] [PubMed]

40. Marsal, J.; Mata, M.; Arbones, A.; Del Campo, J.; Girona, J.; Lopez, G. Factors involved in alleviating water stress by partial crop removal in pear trees. Tree Physiol. 2008, 28, 1375-1382. [CrossRef] [PubMed]

41. Keller, M.; Smithyman, R.P.; Mills, L.J. Interactive effects of deficit irrigation and crop load on Cabernet Sauvignon in an arid climate. Am. J. Enol. Vitic. 2008, 59, 221-243.

42. Uriarte, D.; Intrigliolo, D.S.; Mancha, L.A.; Picón-Toro, J.; Valdes, E.; Prieto, M.H. Interactive Effects of Irrigation and Crop Level on Tempranillo Vines in a Semiarid Climate. Am. J. Enol. Vitic. 2014, 66, 101-111. [CrossRef]

43. Bravdo, B.; Hepner, Y.; Loinger, C.; Cohen, S.; Tabacman, H. Effect of irrigation and crop level on growth, yield and wine quality of Cabernet Sauvignon. Am. J. Enol. Vitic. 1985, 36, 132-139.

44. Keller, M.; Mills, L.J.; Wample, R.L.; Spayd, S.E. Cluster thinning effects on three deficit-irrigated Vitis vinifera cultivars. Am. J. Enol. Vitic. 2005, 56, 91-103.

45. Chapman, D.M.; Roby, G.; Ebeler, S.E.; Guinard, J.-X.; Matthews, M.A. Sensory attributes of Cabernet Sauvignon wines made from vines with different water status. Aust. J. Grape Wine Res. 2005, 11, 339-347. [CrossRef]

46. Guidoni, S.; Allara, P.; Schubert, A. Effect of cluster thinning on berry skin anthocyanin composition of Vitis vinifera cv. Nebbiolo. Am. J. Enol. Vitic. 2002, 53, 224-226.

47. Uriarte, D.; Intrigliolo, D.S.; Mancha, L.A.; Valdés, E.; Gamero, E.; Prieto, M.H. Combined effects of irrigation regimes and crop load on 'Tempranillo' grape composition. Agric. Water Manag. 2016, 165, 97-107. [CrossRef]

48. Ough, C.; Nagaoka, R. Effect of cluster thinning and vineyard yields on grape and wine composition and wine quality of Cabernet Sauvignon. Am. J. Enol.Vitic. 1984, 35, 30-34.

49. Picón-Toro, J.; González-Dugo, V.; Uriarte, D.; Mancha, L.A.; Testi, L. Effects of canopy size and water stress over the crop coefficient of a "Tempranillo" vineyard in south-western Spain. Irrig. Sci. 2012, 30, 419-432. [CrossRef]

50. Baggiolini, M. Les stades repères dans le développement annuel de la vigne et leur utilisation pratique. Revue romande d'Agriculture et d'Arboriculture 1952, 8, 4-6.

51. Eichhorn, K.W.; Lorenz, D.H. Phöenologische Entwicklungsstadie; Der rebe. Nachrichtenb. Deutsch Pflanzenschutzd: Braunschweig, Germany, 1977; pp. 119-120.

52. Martí, P.; González-Altozano, P.; López-Urrea, R.; Mancha, L.A.; Shiri, J. Modeling reference evapotranspiration with calculated targets. Assessment and implications. Agric. Water Manag. 2015, 149, 81-90. [CrossRef]

53. Netzer, Y.; Yao, C.; Shenker, M.; Bravdo, B.-A.; Schwartz, A. Water use and the development of seasonal crop coefficients for Superior Seedless grapevines trained to an open-gable trellis system. Irrig. Sci. 2009, 27, 109-120. [CrossRef]

54. Williams, L.; Phene, C.J.; Grimes, D.W.; Trout, T.J. Water use of mature Thompson Seedless grapevines in California. Irrig. Sci. 2003, 22, 11-18. [CrossRef]

55. Shackel, K.A.; Ahmadi, H.; Biasi, W.; Buchner, R.; Goldhamer, D.; Gurusinghe, S.; Hasey, J.; Kester, D.; Krueger, B.; Lampinen, B.; et al. Plant Water Status as an Index of Irrigation Need in Deciduous Fruit Trees. HortTechnology 1997, 7, 23-29. [CrossRef]

56. OIV. Recueil des Methodes Internationales d'Analyse des Vins et des Moût; Organisation Internationale de la Vigne et du Vin: Paris, France, 1990.

57. Blouin, J. Manual practique d'analyses des moûts et des vins; Fédération des CEIOE Gironde: Bordeaux, France, 1973.

58. Iland, P.G.; Bruer, N.; Wilkes, E.; Edwards, G. Chemical Analysis of Grapes and Wine: Techniques and Concepts, 1st ed.; Winetitles: Broadview, Australia, 2005. 
59. Van Leeuwen, C.; Trégoat, O.; Choné, X.; Bois, B.; Pernet, D.; Gaudillère, J.-P. Vine water status is a key factor in grape ripening and vintage quality for red Bordeaux wine. How can it be assessed for vineyard management purposes? OENO One 2009, 43, 121-134. [CrossRef]

60. Williams, L.E. Growth of "Thompson Seedless" grapevine. I. Leaf area development and dry weight distribution. J. Am. Soc. Hort. Sci. 1987, 112, 325-330.

61. Higgins, S.; Larsen, F.; Bendel, R.; Radamaker, G.; Bassman, J.; Bidlake, W.; Wir, A. Comparative gas exchange characteristics of potted, glasshouse-grown almond, apple, fig, grape, olive, peach and Asian pear. Sci. Hortic. 1992, 52, 313-329. [CrossRef]

62. Schultz, H.R. Differences in hydraulic architecture account for near-isohydric and anisohydric behaviour of two field-grown Vitis vinifera L. cultivars during drought. Plant.Cell Environ. 2003, 26, 1393-1405. [CrossRef]

63. Blanco-Cipollone, F.; Lourenço, S.; Silvestre, J.; Conceição, N.; Moñino, M.J.; Vivas, A.; Ferreira, M.I. Plant Water Status Indicators for Irrigation Scheduling Associated with Iso- and Anisohydric Behavior: Vine and Plum Trees. Horticulturae $2017,3,47$. [CrossRef]

64. Intrigliolo, D.S.; Castel, J.R. Evaluation of grapevine water status from trunk diameter variations. Irrig. Sci. 2007, 26, 49-59. [CrossRef]

65. Hugalde, I.P.; Vila, H.F. Comportamiento isohídrico o anisohídrico en vides . . ¿Una controversia sin fin? RIA 2014, 40, 75-82.

66. Lovisolo, C.; Hartung, W.; Schubert, A. Whole-plant hydraulic conductance and root-to-shoot flow of abscisic acid are independently affected by water stress in grapevines. Funct. Plant. Biol. 2002, 29, 1349-1356. [CrossRef]

67. Rogiers, S.Y.; Greer, D.H.; Hatfield, J.M.; Hutton, R.J.; Clarke, S.J.; Hutchinson, P.A.; Somers, A. Stomatal response of an anisohydric grapevine cultivar to evaporative demand, available soil moisture and abscisic acid. Tree Physiol. 2011, 32, $249-261$. [CrossRef]

68. Intrigliolo, D.S.; Castel, J.R. Vine and soil-based measures of water status in a Tempranillo vineyard. Vitis 2006, 45, 157-163. [CrossRef]

69. Pérez, M.A. Densidad de plantación y riego: Aspectos ecofisiológico, agronómicos y calidad de la uva en cv. Tempranillo (Vitis vinifera L.). Ph.D. Thesis, Universidad Politécnica de Madrid, Madrid, Spain, 2002.

70. Russell, G.L.; Jarvis, P.; Monteith, J. Absorption of radiation by canopies and stand growth. Plant. Canopies 1989, 21-40. [CrossRef]

71. Junquera, P.; Sánchez, P.; de la Fuente, M.; Lissarrague, J.R. Influencia de las características geométricas de viñedos de la variedad Tempranillo conducidos en espaldera en la interceptación de radiación solar. In Proceedings of the XIV National Congress of Horticultural Sciences, Orihuela, Spain, 4 June 2015.

72. Medrano, H.; Escalona, J.M.; Cifre, J.; Bota, J.; Flexas, J. A ten-year study on the physiology of two Spanish grapevine cultivars under field conditions: Effects of water availability from leaf photosynthesis to grape yield and quality. Funct. Plant. Biol. 2003, 30, 607-619. [CrossRef] [PubMed]

73. Loveys, B.R.; Csiro, P.E.K. Rapid Changes in Abscisic Acid-like Inhibitors Following Alterations in Vine Leaf Water Potential. Physiol. Plant. 1973, 28, 476-479. [CrossRef]

74. Bradford, K.J.; Hsiao, T.C. Physiological Responses to Moderate Water Stress. In Physiological Plant Ecology II. (New Series); Lange, O.L., Nobel, P.S., Osmond, C.B., Ziegler, H., Eds.; Springer: Berlín/Heidelberg, Germany, 1982; Volume 12, pp. 263-324.

75. Samperio, A.; Moñino, M.J.; Vivas, A.; Blanco-Cipollone, F.; Martín, A.G.; Prieto, M.H. Effect of deficit irrigation during stage II and post-harvest on tree water status, vegetative growth, yield and economic assessment in 'Angeleno' Japanese plum. Agric. Water Manag. 2015, 158, 69-81. [CrossRef]

76. Hardies, W.Y.; Considine, J.A. Response of grapes to water-deficit stress in particular stages of development. Am. J. Enol. Vitic. 1976, 27, 55-61.

77. McCarthy, M.G. Water stress at flowering and effects on yield. In Transforming Flowers to Fruit; ASVO: Mildura, Australia, 2005; pp. 35-37.

78. Myburgh, P. Responses of Vitis vinifera L. cv. Sultanina to Water Deficits During Various Pre- and Post-Harvest Phases Under Semi-Arid Conditions. South. Afr. J. Enol. Vitic. 2017, 24, 25-33. [CrossRef]

79. Skinner, P.; Matthews, M. Reproductive development in grape (Vitis vinifera L.) under phosphorus-limited conditions. Sci. Hortic. 1989, 38, 49-60. [CrossRef]

80. McCarthy, M.G.; Loveys, B.R.; Dry, P.R.; Stoll, M. Regulated deficit irrigation and partial rootzone drying as irrigation management techniques for grapevines. In Deficit Irrigation Practices; FAO Water Reports No 22; FAO: Rome, Italy, $2002 ;$ pp. $79-87$.

81. Greven, M.; Raw, V.; West, B.A. Effects of timing of water stress on yield and berry size. Water Sci. Technol. 2009, 60, 1249-1255. [CrossRef]

82. Esteban, M.A.; Villanueva, M.J.; Lissarrague, J.R. Effect of irrigation on changes in berry composition of Tempranillo during maturation. Sugars, organic acids and mineral elements. Am. J. Enol. Vitic. 1999, 50, 418-434.

83. García-Escudero, E.; Ibáñez, S.; Villar, M.; García, C.; Romero, I.; López, D. Influencia del riego sobre parámetros vegetoproductivos y de calidad del mosto y del vino en las variedades Tempranillo, Garnacha Tinta, Graciano y Cabernet Sauvignon. Enólogos 2006, 41, 30-35.

84. Salón, J.L.; Chirivella, C.; Castel, J.R. Response of cv. Bobal to timing of deficit irrigation in Requena, Spain: Water relations, yield and wine quality. Am. J. Enol. Vitic. 2005, 56, 1-8.

85. Ojeda, H.; Deloire, A.; Wang, Z.; Carbonneau, A. Determinación y control del estado hídrico de la vid. Efectos morfológicos y fisiológicos de la restricción hídrica en vides. Enología 2008, 6, 1-15. 
86. Smart, R.E. Principles of grapevine canopy microclimate manipulation with implications for yield and quality. A review. Am. J. Enol. Vitic. 1985, 36, 230-239.

87. Castel, J.R.; Valdés, E.; Prieto, M.H.; Uriarte, D.; Mancha, L.; Montoro, A.; Mañas, F.; López-Urrea, R.; López-Fuster, P.; Yuste, J.; et al. Efecto del clima y suelo sobre la respuesta al riego de Tempranillo (I). La Sem. Vitivinícola 2013, 3393, $198-206$.

88. Rubio, J.A. Riego y aclareo de racimos: Efectos en la actividad fisiológica, en el control del rendimiento y en la calidad de la uva del cv. Tempranillo (Vitis vinifera L.). Ph.D. Thesis, Universidad Politécnica de Madrid, Madrid, Spain, 2002.

89. Hale, C.R. Relation between potassium and the malate and tartrate contents of grape berries. Vitis 1977, 16, 9-19.

90. Lissarrague, J.R. Estudio de los efectos del riego en la producción, desarrollo vegetativo, calidad de los mostos y nutrición mineral de la vid (Vitis vinifera L.). Ph.D. Thesis, Universidad Politécnica de Madrid, Madrid, Spain, 1986.

91. Smart, R.E.; Turkington, C.R.; Evans, J.C. Grapevine response to furrow and trickle irrigation. Am. J. Enol. Vitic. 1974, 25, 62-66.

92. García-Escudero, E.; López, R.; Santamaría, P.; Zaballa, O. Ensayos de riego localizados en viñedos productivos de cv. Tempranillo. Vitic. Enol. Prof. 1997, 50, 35-47.

93. García-Escudero, E.; López, R.; Santamaría, P.; Zaballa, O. Control del rendimiento en viñedos conducido en régimen de riego localizado. Vitic. Enol. Prof. 2000, 69, 12-24.

94. Carbonneau, A.; Casteran, P.; Leclair, P. Application ál 'étude synthétique des principaux facteurs du milieu expliquant la hiebarchie des crus; Vignes et Vins: Lyon, France, 1982; September Special Issue.

95. Freeman, B.M.; Kliewer, W.M. Effects of irrigation, crop level and potassium fertilization on Carignane vines. II. Grapes and wine quality. Am. J. Enol. Vitic. 1983, 34, 197-206. 